\title{
50. VØRING PLATEAU CONTINENTAL MARGIN: SEISMIC INTERPRETATION, STRATIGRAPHY, AND VERTICAL MOVEMENTS1
}

\author{
Jakob Skogseid and Olav Eldholm ${ }^{2}$
}

\begin{abstract}
Seismic mapping tied to drilling data has provided a depositional, structural, and volcanic framework that describes the Vøring Plateau continental margin since Late Jurassic time. The Vøring Basin was structured by Late Jurassic-Early Cretaceous extension and subsequent subsidence in the Cretaceous. It is divided into two basin provinces by the MoldeBod $\sigma$ high. The opening of the Norwegian-Greenland Sea during the early Tertiary was preceded by uplift of the outer Vøring Basin accompanied by extensional listric faulting in the Cretaceous sediments and intrusive activity. The early Tertiary extension was restricted to the outer Vøring Basin, subsequently forming the Tertiary marginal basin. The igneous activity is also restricted to this basin, gradually approaching the Vøring Plateau Escarpment toward the time of breakup. Initial subaerial sea-floor spreading created the upper volcanic series at ODP Site 642, parts of the flow-sill complex landward of the escarpment and also caused deposition of ashes and tuffs in the Vøring Basin. The post-opening margin history is characterized by the progressive submergence of the Vøring Plateau marginal high which for long periods was elevated with respect to the Vøring Basin. The southern marginal high became fully sediment covered during the early Miocene, whereas the northern part was not covered before the Pliocene. The basal sediments are of terrigenous origin, partly derived from erosion of the exposed lavas. Off the summit, a change to hemipelagic and pelagic compositions took place during the middle and late Eocene. The overall sediment record at the high is characterized by local erosion, redeposition, and instabilities. We propose that early Tertiary strike-slip motion, which triggered mass movements lasting into the early Miocene, is responsible for the spectacular north-south domes in the Vøring Basin. Finally, a renewed major pulse of sedimentation and subsidence centered on the shelf edge commenced in latest Miocene time.
\end{abstract}

\section{INTRODUCTION}

Continuous coring during Ocean Drilling Program (ODP) Leg 104 at the outer Vøring Plateau provided a unique opportunity to study the history of this Cenozoic continental margin. By tying the drilling results to seismic data we have derived an improved geologic framework that has implications not only for the Vøring Plateau Margin, but also for the entire continental margin off Norway (Fig. 1).

The depositional and structural history of the margin off Norway is reviewed by Eldholm, Thiede, and Taylor in the introduction to this volume. The first seismic investigations were single-channel profiling and velocity measurements primarily using expendable sonobuoys (Talwani and Eldholm, 1972; Eldholm and Windisch, 1974). Despite limited penetration this work outlined a number of important geological features at the outer Vøring Plateau Margin (Fig. 2). Among these were: The Jan Mayen Fracture Zone, the Vøring Plateau Escarpment, a shallow acoustic basement surface constituting a marginal high seaward of the escarpment, the large sedimentary Voring Basin landward of the escarpment, and a structural high with spectacular diapirism in the northern Vøring Basin.

Deep Sea Drilling Project (DSDP) Leg 38, which was planned on the basis of single-channel seismic data, drilled three shallow holes in the Vøring Basin $(339,340,341)$; two holes to basement at the marginal high $(338,342)$; and one hole (343) near the foot of the Vøring Plateau (Talwani, Udintsev, et al., 1976) (Fig. 3). A major result was the confirmation that the acoustic basement reflector west of the escarpment was caused by basalts. Furthermore, the recovered sediments formed the basis for the first

\footnotetext{
${ }^{1}$ Eldholm, O., Thiede, J., Taylor, E., et al., 1989. Proc. ODP, Sci. Results, 104: College Station, TX (Ocean Drilling Program).

2 Department of Geology, University of Oslo, PO Box 1047, N-0316 Blindern, Oslo 3, Norway.
}

stratigraphic interpretation (Caston, 1976), which has not been considerably changed by later studies (Hinz et al., 1984; Mutter, 1984).

During the last decade most seismic surveys have relied on multichannel seismic (MCS) profiling supplemented by velocity measurements using digital sonobuoys and expanded spread profiles (ESP). Presently, a dense grid of MCS lines recorded as a part of the exploration efforts off mid-Norway covers the continental shelf. This activity also included a number of commercial wells within the areas shown in Figure 2 (Dalland and Worsley, 1988). A regional grid of MCS profiles acquired by the Norwegian Petroleum Directorate (NPD) and various research institutions exists on the continental slope, including a number of profiles extending onto the oceanic crust in the Lofoten Basin (Fig. 3). The most recent regional interpretations of the MCS lines seaward of the shelf edge includes those of Bøen et al. (1984), Hinz et al. (1984), Mutter (1984), Bukovics and Ziegler (1985), Hagevang and Rónnevik (1986), and Brekke and Riis (1987). Velocity-depth curves from digitally recorded sonobuoy and expanded spread profiles have been presented by Mutter et al. (1984), Eldholm and Mutter (1986), Hinz et al. (1987), and Mutter and Zehnder (1988).

In this paper we have mapped the main sedimentary sequences and structural features at the Vøring Plateau marginal high and in the Vøring Basin. For completeness, a brief summary of the sub-basement seismic sequences seaward of the Vøring Plateau Escarpment is included. By correlation with dated sequences on the continental shelf as well as the DSDP and ODP drill sites at the Vøring Plateau, we attempt to further develop the sequence stratigraphy and structural setting of the Vøring Plateau Margin. In particular, we are concerned with how depositional, tectonic, and volcanic evolution relate to the history of vertical motion. While we focus on the Cenozoic events, the pre-Cenozoic Voring Basin is discussed because there is a significant interrelationship between the preopening and later geologic features. 


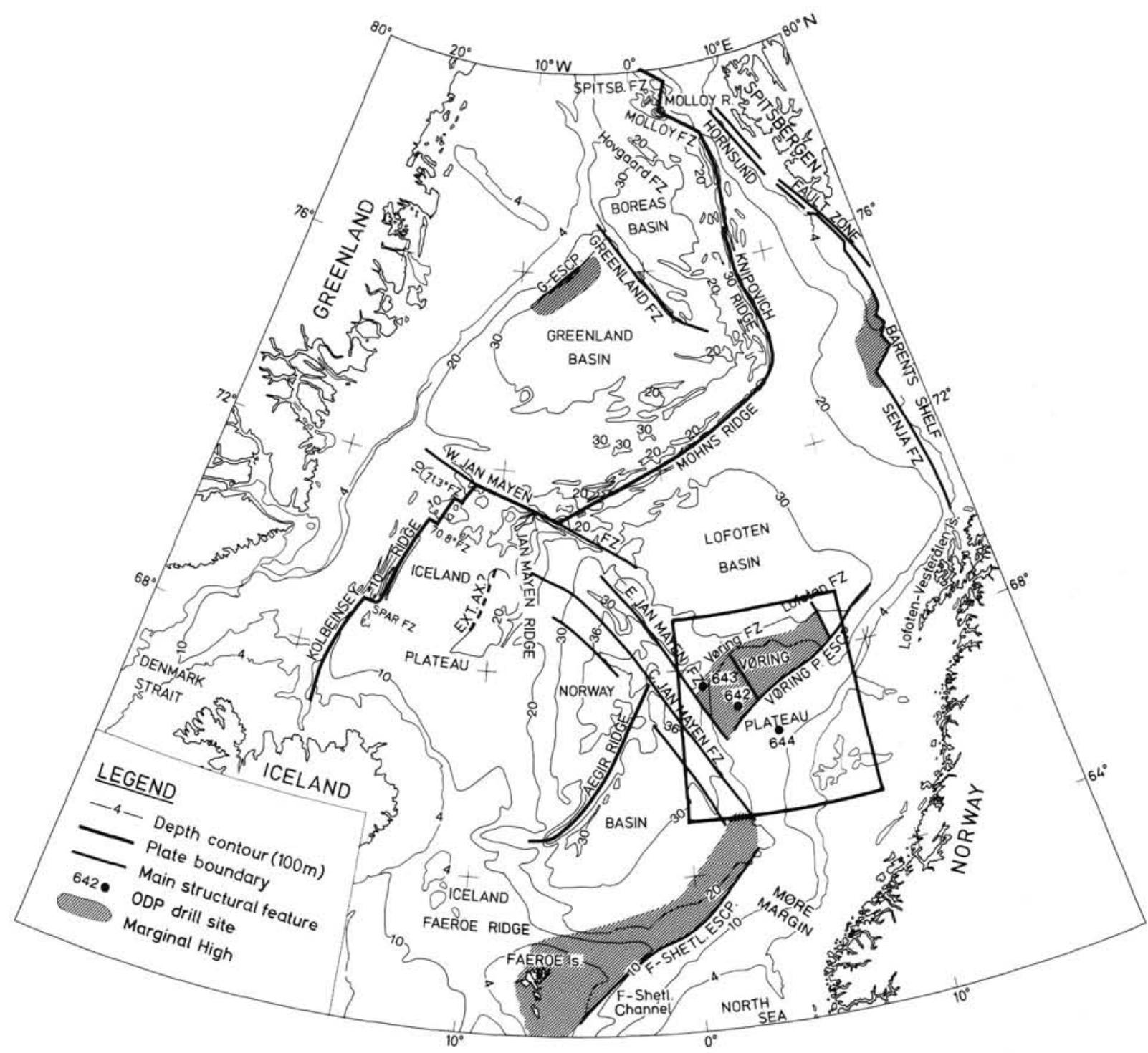

Figure 1. ODP Leg 104 drill sites, regional physiography, and structural features of the ocean basins and continental margins in the Norwegian-Greenland Sea. Slightly modified from Eldholm et al. (1989). Box shows Vøring Plateau margin study area.

\section{INTERPRETATION PROCEDURE}

The seismic interpretation is based on about $10,000 \mathrm{~km} \mathrm{MCS}$ and about $2000 \mathrm{~km}$ single-channel seismic profiles (Fig. 3). We have restricted the mapping to a region between the faulted complex west of Trøndelag Platform in the east and the oceanic crust at the base of the Vøring Plateau in the west (Fig. 2).

Several schemes of reflector identification have been used at the Norwegian continental shelf and upper slope north of $62^{\circ} \mathrm{N}$ (Rønnevik and Navrestad, 1977; Jørgensen and Navrestad, 1981; Bukovics et al., 1984) and at the Vøring Plateau (Caston, 1976; Rønnevik et al., 1979; Hinz et al., 1984; Mutter, 1984). Here, the notations of NPD (Jørgensen and Navrestad, 1981), supplemented by additional horizons, have been adopted and are listed below:

UP : Upper Pliocene

$\mathrm{O}^{\prime}$ : Base Pliocene

$\mathrm{MM}$ : Middle Miocene

A : Lower Miocene

$\begin{array}{cc}\begin{array}{c}\text { Vøring } \\ \text { marginal }\end{array} & \begin{array}{c}\text { Vøring } \\ \text { Basin }\end{array} \\ \mathrm{x} & \mathrm{x} \\ \mathrm{x} & \mathrm{x} \\ \mathrm{x} & \mathrm{x}\end{array}$

Vøring marginal Vøring high Basin

$\mathbf{A}^{\prime}$ : Middle Oligocene

ME : Middle Eocene

EE : Lower Eocene flow basalts

TP : Lower Eocene Tuff

IF : Inner flows (Paleocene/Eocene)

$\mathrm{x} \quad \mathrm{x}$

$\mathrm{x}$

K : Top Lower Series (Paleocene/Eocene)

C : Base Tertiary

D' : Middle Cretaceous

D : Base Cretaceous

E : Middle Jurassic

LCR: Lower Crustal Reflector

A number of these reflectors have been dated by ties to commercial wells on the shelf. In addition, the ODP/DSDP sites at the outer margin provide an independent means of dating the main part of the Cenozoic section. For the post-opening sediments this procedure leads to consistent results. In a regional sense, we are generally confident of the seismic correlation and dating. However, the correlation out of the basin in the east and locally across the Vøring Plateau Escarpment is not without 


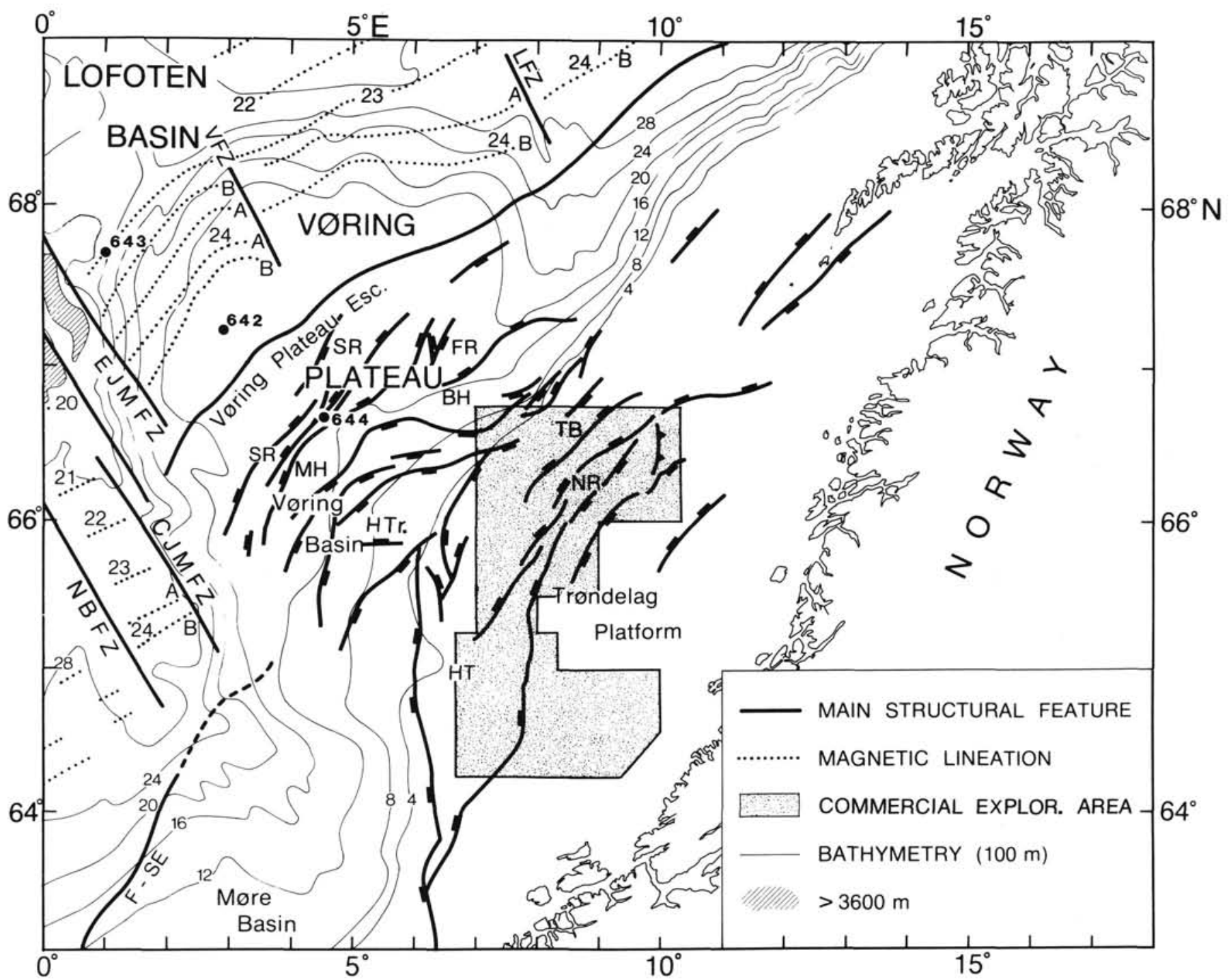

Figure 2. Bathymetry (Perry et al., 1980), sea-floor spreading anomalies (Talwani and Eldholm, 1977; Hagevang et al., 1983), main geological provinces and ODP drill sites at the Vøring Plateau margin. F-SE: Faeroe-Shetland Escarpment; NBFZ: Norway Basin Fracture Zone; CJMFZ: Central Jan Mayen Fracture Zone; EJMFZ: East Jan Mayen Fracture Zone; VFZ: Vøring Fracture Zone; LFZ: Lofoten Fracture Zone; NR: Nordland Ridge; TB: Traen Basin, HT: Halten Terrace; HT: Halten Trough; MH: Molde high; BH: Bodø high; SR: Smøla Rift, FR: Fleina Rift.

ambiguity. Furthermore, the seismic interpretation in the locally deformed areas of the Vøring Basin is considered tentative. Finally, we stress that some of the reflector notations, for example upper Pliocene, do not indicate an exact geological position but refer to a regionally defined reflector level.

\section{VØRING BASIN}

\section{Mesozoic Configuration}

The Vøring Basin constitutes a large Mesozoic sedimentary basin province developed by regional subsidence in the Cretaceous. Structuring into the Trøndelag Platform region and the Vøring Basin (Figs. 2 and 4) was established by the Late Jurassic-Early Cretaceous tectonic episode. The base Cretaceous reflector (Fig. 5) shows that this episode created a tectonic surface comprising many structural features. Some of these have been given formal names by Gabrielsen et al. (1984). Because the Vøring Basin was poorly known at that time, we have had to use several names not formally recognized.

The seismic data and drilling results document the existence of earlier basins between Norway and Greenland in which con- siderable sediment thicknesses had been deposited (Rønnevik and Navrestad, 1977; Bukovics et al., 1984; Larsen, 1987; Dalland and Worsley, 1988). The seismic resolution deteriorates below the base-Cretaceous level in the Vøring Basin, although a sequence of subparallel reflectors is observed. Within this sequence reflector E, of probable middle Jurassic age (Jørgensen and Navrestad, 1981), is recognized (Fig. 5). A minimum of 3 $\mathrm{km}$ pre-Cretaceous sediments is inferred from the seismic profiles and seismic velocity measurements (Eldholm and Mutter, 1986). Thus, the pre-Cretaceous thickness in the Vøring Basin might be comparable with the eastern platform region (Hollander, 1984). This region documents several tectonic events prior to the Cretaceous period. These are the early Carboniferous to Permian and the Triassic/Early Jurassic to middle/Late Jurassic rift episodes (Bukovics et al., 1984; Brekke and Riis, 1987). We believe that the deep part of the basin contains a series of pre-Cretaceous, probably Permian to Jurassic, deposits that were part of the older epicontinental basin.

We do not recognize reflectors that could represent a deep crystalline basement in the Vøring Basin. However, a strong continuous lower crustal reflector (LCR) at about $12-15 \mathrm{~km}$ 


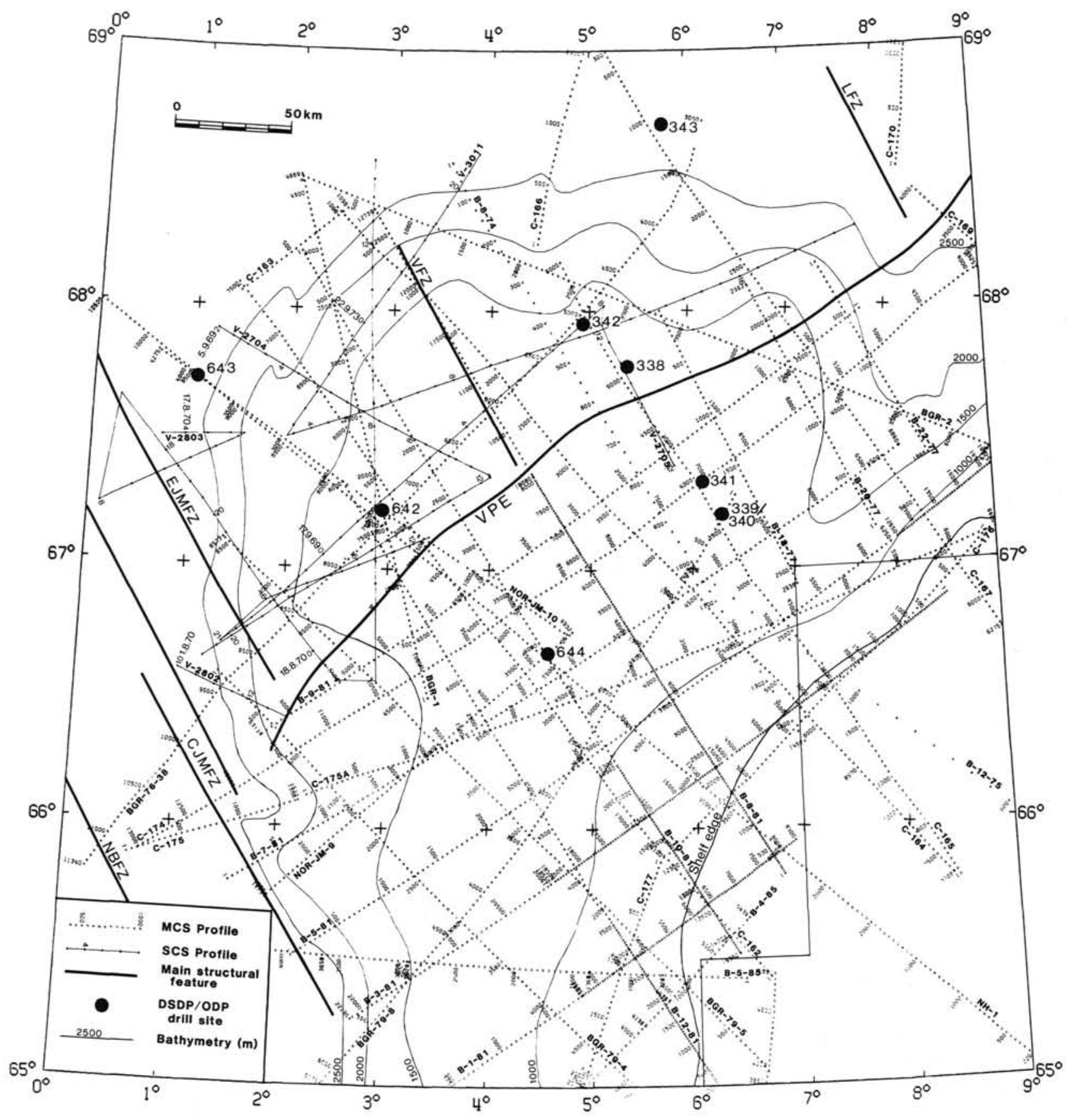

Figure 3. Track chart showing location of single and multichannel seismic profiles and DSDP/ODP drill sites used in this study. Area opened for commercial exploration indicated by the box in the lower right hand corner. VPE: Vøring Plateau Escarpment. Other abbreviations as in Figure 2.

depth is observed locally beneath the Smøla Rift, a short distance east of the Vøring Plateau Escarpment (Fig. 5).

The base-Cretaceous reflector (Fig. 5) shows that the surface created by the late Jurassic-early Cretaceous extensional episode later experienced differential subsidence. At the Nordland Ridge, the Halten Terrace and the eastern flank of the Vøring Basin, the reflector is an erosional unconformity that is truncating the Jurassic fault blocks, thus postdating the actual faulting. Brekke and Riis (1987) show that this region stayed relatively elevated until middle Cretaceous times, when the entire Trøndelag Platform and Halten Terrace was tilted to the west causing a contemperaneous transgression. In the central and western part of the Vøring Basin the base Cretaceous reflector is offset by the Late Jurassic-Early Cretaceous faults revealing an early Cretaceous subsidence without appreciable erosion (Fig. 5). A consequence of our mapping, as well as of earlier studies, is that the reflector is slightly time-transgressive out of the basin in the east. Although the character changes over the basin, it is generally easy to follow because of the high amplitude and the fact that it is the first strong, continuous horizon below the base of the Tertiary (Fig. 6).

The Late Jurassic-Early Cretaceous tectonism formed a number of well-defined intrabasinal structures (Figs. 4, 5). The eastern basin province includes the Traen Basin, the Halten Trough 


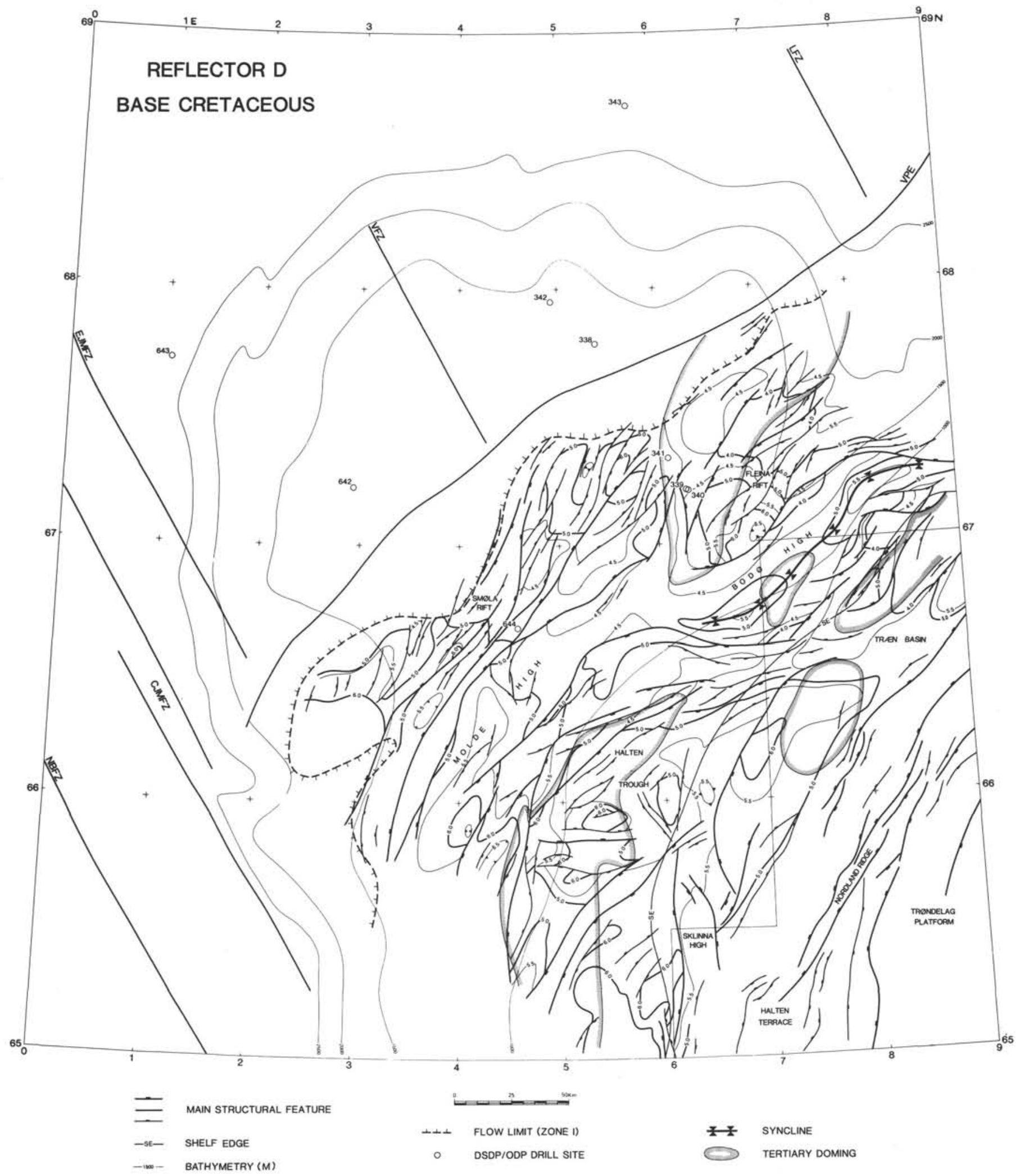

Figure 4. Isochrone and structural map at the base-Cretaceous level, reflector D. Areas of Paleogene doming are superimposed on the base-Cretaceous relief. Contour interval $0.5 \mathrm{~s}$. Abbreviations in Figure 2. 
NW
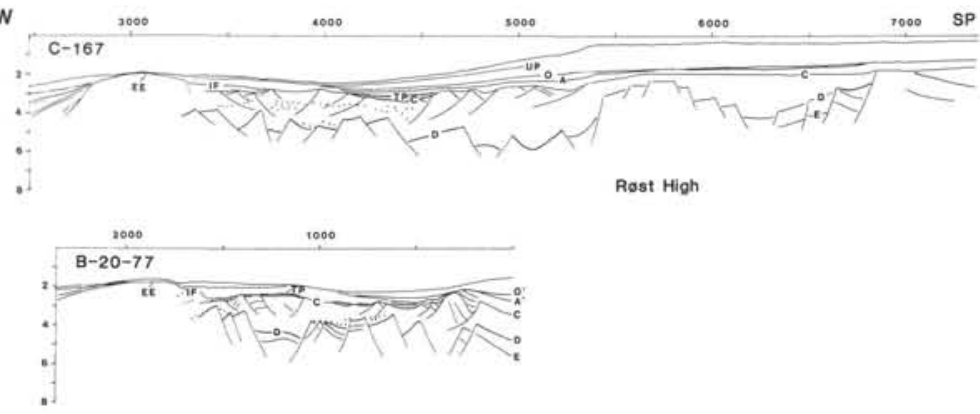

SE
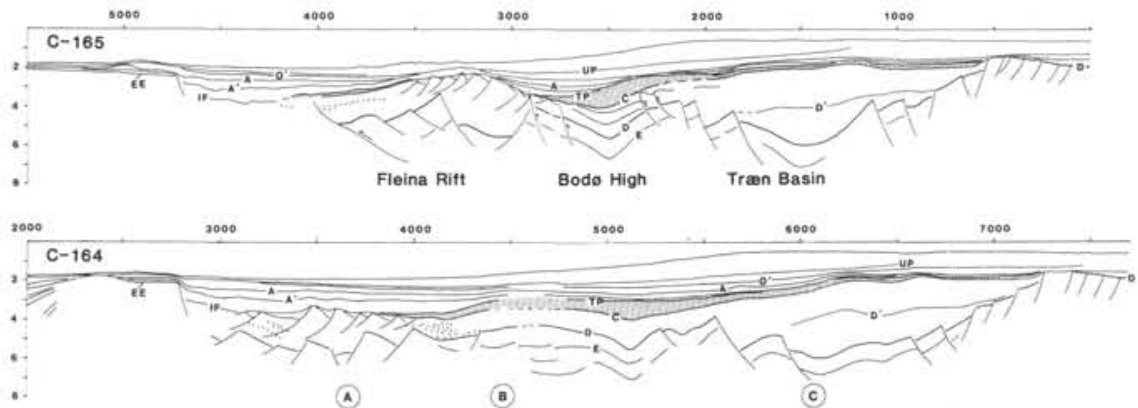

(A)

(3)

(c)

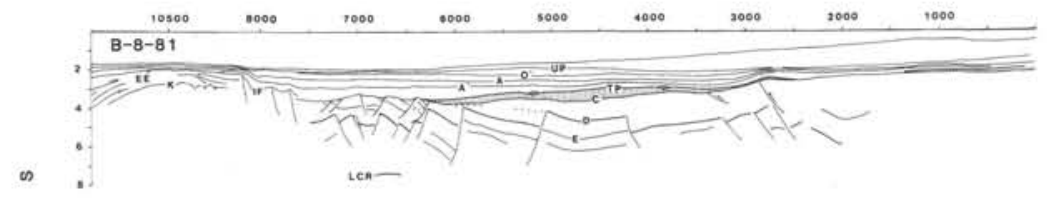

$\stackrel{5}{\xi}$
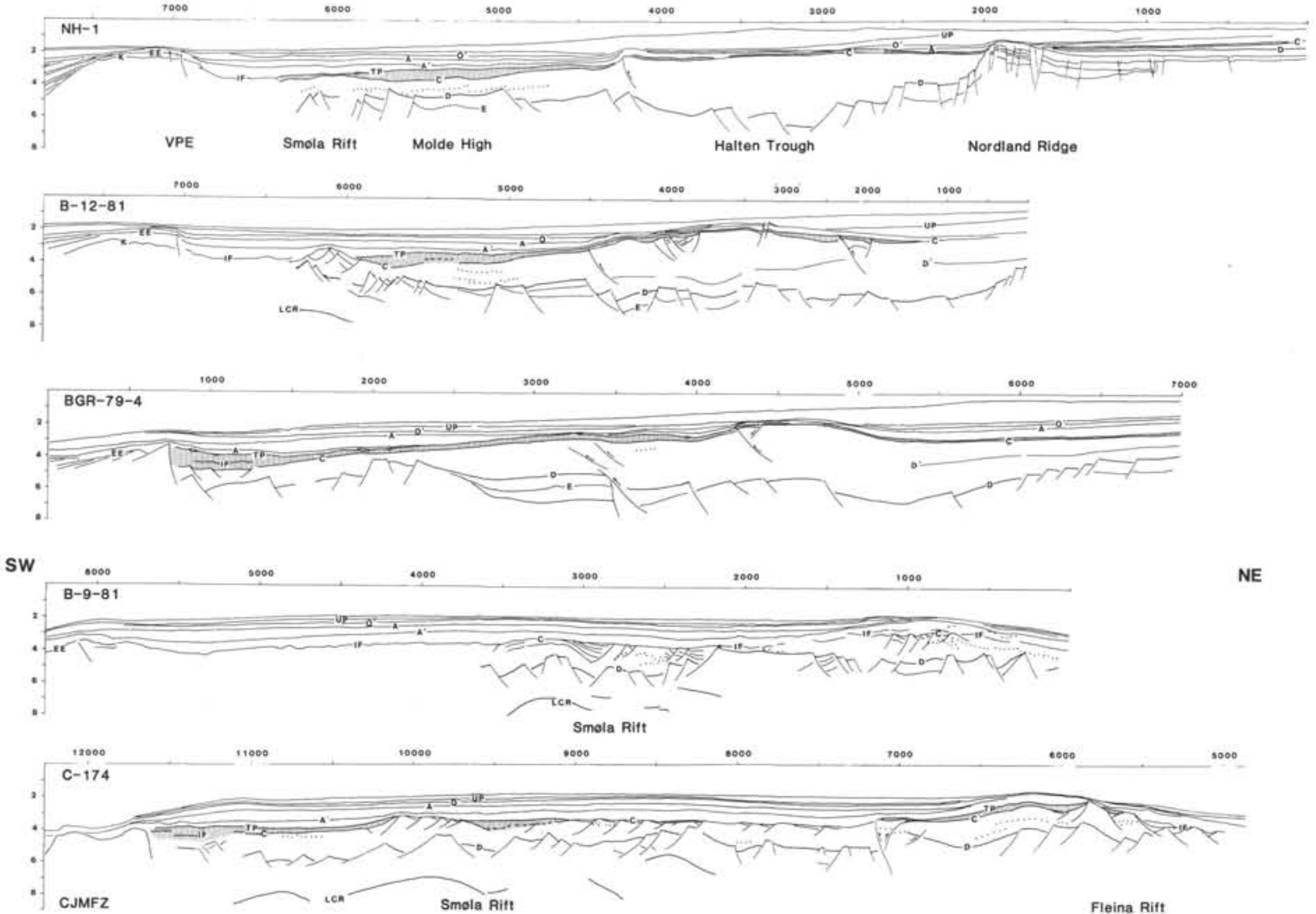

Figure 5. Interpreted seismic sections in the Vøring Basin. Paleocene sediments indicated by shading and intrusives in the Cretaceous sequence dotted. Selected tectonic subsidence curves calculated at pseudowells in the vicinity of profile C-164 from Pedersen and Skogseid (this volume). Profile locations in Figure 3. Note that profiles B-9-81 and C-174 are strike lines along the outer Vøring Basin. Abbreviations as in Figure 2. For reflector nomenclature, see text. 


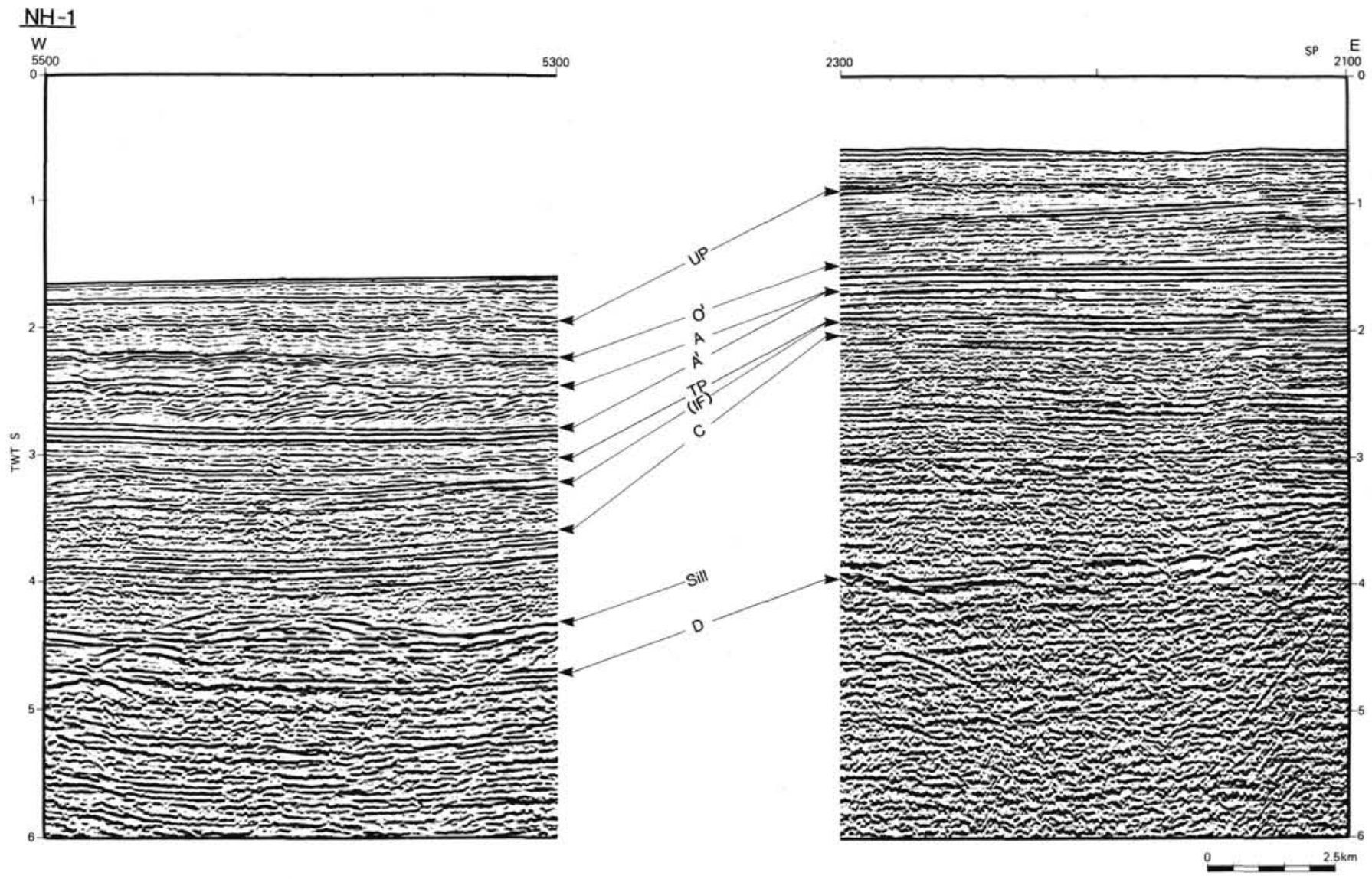

Figure 6. Seismic sections demonstrating the contrast between the outer and inner Vøring Basin sedimentary sequences. Profile location shown in Figure 3. For reflector nomenclature, see text.

and the Halten Terrace bounded eastward by a major fault system along the outer flank of the Nordland Ridge. To the west, the Halten Trough and the Traen Basin terminate against the Molde high and Bodø high respectively. The highs forms a prominent ridge system across the entire Vøring Basin separating the eastern basin province from the Smøla Rift and a separate, extensional depression farther north which we have named the Fleina Rift. These rifts constitute the western basin province. The Fleina Rift is a northeasterly plunging rift depression north of $66^{\circ} 50^{\prime} \mathrm{N}$. In the south it is a single narrow rift becoming broader and more complex to the north (Figs. 4, 5). Note that the Bodø high includes a sharp synclinal feature, earlier named the Røst Syncline (Rønnevik et al., 1983; Bøen et al., 1984) and the Røst Sub-basin (Gabrielsen et al., 1984), along its entire length. Also note that the term Molde high was first used by Hamar and Hjelle (1984) to describe a dome mapped by Hinz et al. (1982). Later, Bukovics et al. (1984) and Brekke and Riis (1987) applied it to a structure at the reflector D level partly below the dome. We have continued this intrabasinal high northward, thus giving the Molde high a more regional extent than previously inferred.

The Late Jurassic extensional surface was smoothed by sedimentation in the Early Cretaceous, although local highs stayed emerged as late as mid-Cretaceous time (Fig. 5). Subsequent regional subsidence created conditions for increased deposition and a 1- to 2- $\mathrm{s}$ thick section, with maximum thicknesses in the Halten Trough and Fleina Rift, was laid down since middle Cre- taceous time. The total Cretaceous sediment thickness, however, exhibits a maximum in the eastern basin province.

The absence of regionally continuous reflectors within the Cretaceous sequence and the regional setting indicate homogeneous sediments, probably a considerable component of marine shales. On the other hand, Hastings (1986) reports reflective Cenomanian sandstones within the shales at the Halten Terrace. We have traced a middle Cretaceous marker (reflector D', Fig. 5), across the Halten Trough and the Traen Basin toward the MoldeBodø high, showing that the highs are without a Lower Cretaceous cover. Within the western rifts there is again an increase in internal reflectivity that might reflect coarser sediment components, possibly derived from erosion of the adjacent highs.

Throughout the Cretaceous period the Halten Trough and Traen Basin were the main depocenters, whereas the western basin province had subsided less. However, the Cretaceous sediment thickness increases in the Fleina Rift region (Fig. 5). We believe this reflects the structural division of the Vøring Basin by the Molde-Bodø high (Fig. 4). In the south, maximum Late Jurassic crustal extension probably took place landward of the Molde high. Farther north, the main area of extension was west of the Bodø high, which established the Fleina Rift as the main depocenter.

\section{Cenozoic Basin}

The Cenozoic tectonic and depositional history is closely linked to the phase of renewed crustal extension leading to con- 
tinental separation between Norway and Greenland during the earliest Eocene. The extensional event was initiated a few million years, possibly as much as $10 \mathrm{~m}$.y., prior to the final continental separation marked by the formation of oceanic crust $57 \mathrm{Ma}$. During this period the outer Vøring Basin, particularly the Smøla and Fleina Rifts, experienced structural deformation, uplift, and erosion. Later, thermal subsidence led to deposition of a 1.0- to 1.5-s thick sequence of Paleogene sediments. However, the inner part of the Vøring Basin was not affected by the extension nor by the subsequent subsidence (Figs. 5 and 6). Consequently, we divide the Paleogene Vøring Basin into an outer Tertiary marginal basin characterized by differential extension and subsidence, and an inner relatively stable region. This configuration is expressed by the base Tertiary contours (Fig. 7) showing that the marginal basin is bounded to the east by a distinct gradient $100-150 \mathrm{~km}$ east of the Vøring Plateau Escarpment.

The extension of the outer basin is also documented by a listric fault system deforming the Cretaceous sediments in the Smøla and Fleina Rifts. The fault geometry is typical for detatched normal faults (Harding and Lowell, 1979). The width of the structural deformation increases northward, extending landward to the eastern rift flanks (Figs. 5, 7). The listric fault planes are detatched within the Cretaceous sediment sequence without observed reactivation of the underlying older structures.

The early Tertiary uplift is particularly well expressed in the Smøla Rift. Here, the uplift increased the tilt of the older baseCretaceous fault blocks and caused doming of the weak intraCretaceous reflectors (profile B-12-81, Fig. 5). The time-transgressive base Tertiary reflector truncates the faulted surface and the absence of lowermost Tertiary sediments (Fig. 8) suggests that the inverted area stayed emergent for some time. From the seismic data, however, it is difficult to determine whether the inversion was contemporaneous or postdated the listric faulting.

Farther east in the basin a different kind of Cenozoic deformation is characterized by two structural components, a complex reversely faulted core overlain by unfaulted updomed beds (Fig. 4). The faults are observed at the base Tertiary, locally also the lower Eocene, and deeper levels (Fig. 5). This implies a latest Cretaceous to earliest Tertiary age of the deformation. The stress system probably had a primary strike-slip component. The deformation, observed in seismic cross sections, is expressed by west-facing reverse faults (Fig. 5), but locally includes normal faults along the eastern flank of the domes. The faulting was followed by a period of gentle updoming lasting until Miocene time, perhaps later in the north where it triggered local diapirism. Profile B-9-81 (Fig. 5) documents that the doming and the early Tertiary uplift in the western basin were caused by two separate stress systems. However, they interacted at the junction between the Smøla and Fleina Rifts, partly causing the complex structuring in Figure 9.

Figure 4 shows that the main doming is restricted to an elongate north to south antiform crossing the entire Vøring Basin. The dome province has been recognized for some time but its nature and evolution is poorly understood (Eldholm et al., 1984). The main area of deformation lies within the Halten Trough north to $66^{\circ} 25^{\prime} \mathrm{N}$ where it is interrupted by the Bod $\varnothing$ high, continuing in the transitional region between the Smøla and Fleina Rifts toward the Vøring Plateau Escarpment. The dome shallows northward, giving rise to pronounced local diapirism reaching the sea floor in the Fleina Rift (Figs. 8, 9). We have named the feature north of the Bod $\varnothing$ high the Vema Dome in recognition of its discovery during $\mathrm{R} / \mathrm{V}$ Vema Cruise 27 . We have also mapped some local elliptical domes following the trend of the Traen Basin (Fig. 4). These are recognized as gentle doming in the base-Tertiary horizon. A similar feature exists over the Bod $\varnothing$ high.
Despite the Paleogene deformation, regional subsidence and sedimentation characterize the evolution of the Vøring Plateau Margin after the continental breakup in the earliest Eocene. In particular, there is a clear relationship between sedimentation and subsidence. The map of the base Tertiary reflector (Fig. 7) generally corresponds to previous work (Bøen et al., 1984; Mutter, 1984; Bukovics and Ziegler, 1985; Hagevang and Rønnevik, 1986), except in the Tertiary marginal basin where we infer a slightly deeper level for the horizon. In the vicinity of the Vøring Plateau Escarpment the base Tertiary reflector is an erosional unconformity truncating the inverted rotated fault blocks in the Smøla and Fleina Rifts (Fig. 5), becoming conformable with the underlying beds east of the rifts. Moreover, it is particularly well-defined below the expanded Paleogene section in the marginal basin, but exhibits much poorer reflectivity to the east where the Paleogene sediments are much thinner (Fig. 6).

The lower Eocene reflector (Fig. 8) has been tied to wells on the shelf where it correlates with a regional marker of ashes and tuffs which are known from wells in the northern North Sea and adjacent areas (Jacqué and Thouvenin, 1975; Knox, 1984; Malm et al., 1984). Recent work of Knox and Morton (1988) shows two distinct volcanic episodes. They correlate the lower mixed rhyolitic-basaltic ash layers with Paleocene explosive volcanism in the Hebridean region, whereas the upper late Paleocene-earliest Eocene basaltic ashes are associated with the generation of oceanic crust in the North Atlantic. The seismic marker lies in NP Zone 10, hence we assign an earliest Eocene age for reflector TP. It is distinct in the eastern basin province, losing sharpness and changing into a narrow band of continuous seismic signals on top of a more transparent sequence westward (Fig. 6). Within the Tertiary marginal basin we notice peculiar, up to 2 $\mathrm{km}$ wide, conic depressions at the level of TP. Some of these features are associated with small local domes in the above-lying sediments (Figs. 8, 10), often also with deeper faults and/or sills. A few features of this kind are observed within the C-TP sequence, but none above reflector TP.

The Paleocene sequence (C-TP) onlaps the base Tertiary horizon in the western Vøring Basin (Figs. 5, 8) except in the southwest where TP extends as far as the Vøring Plateau Escarpment, and onlaps the basement high of the Central Jan Mayen Fracture Zone. In this part of the basin reflector TP lies above the inner flow horizon (Fig. 10). Over the Tertiary domes, TP locally onlaps the base Tertiary horizon, but is also truncated by younger erosional unconformities. This indicates a base-Tertiary relief prior to deposition of TP and that the magnitude of the Tertiary doming was variable in time and space (Fig. 8).

The middle Oligocene reflector $\mathrm{A}^{\prime}$ (Fig. 11) is an erosional unconformity east of the Tertiary marginal basin where the entire pre-Pliocene Cenozoic section is condensed and $A^{\prime}$ truncates the older sediments. On the other hand, $A^{\prime}$ is cut by the lower Miocene horizon. Within the marginal basin, $\mathrm{A}^{\prime}$ forms the top of a band of reflectors conformable with the underlying beds. In this region it is the uppermost reflector of good continuity contrasting with those above which are disturbed by settling features, shallow gas, and ice-rafted material in the uppermost section (Fig. 6). We believe this in part reflects a depositional transition from shallow marine to hemipelagic and pelagic conditions during the late Oligocene.

The lower Miocene reflector A (Fig. 12) is recognized over the entire study area. Although it is broken into numerous short segments in the western Vøring Basin, lateral correlation is normally maintained (Fig. 6). The seismic continuity improves over the highs and in the eastern basin where the horizon is erosional and truncated by the base Pliocene horizon locally.

The base Pliocene erosional unconformity, reflector $\mathrm{O}^{\prime}$ (Fig. 13), marks the base of a huge sequence of Pliocene-Pleistocene sediments prograding westward and downlapping onto $\mathrm{O}^{\prime}$. However, the unconformity gradually loses distinction and the overlying sediments thin towards the western basin where the base Pliocene and upper Pliocene reflectors merge. The latter horizon is mapped over the entire margin. 


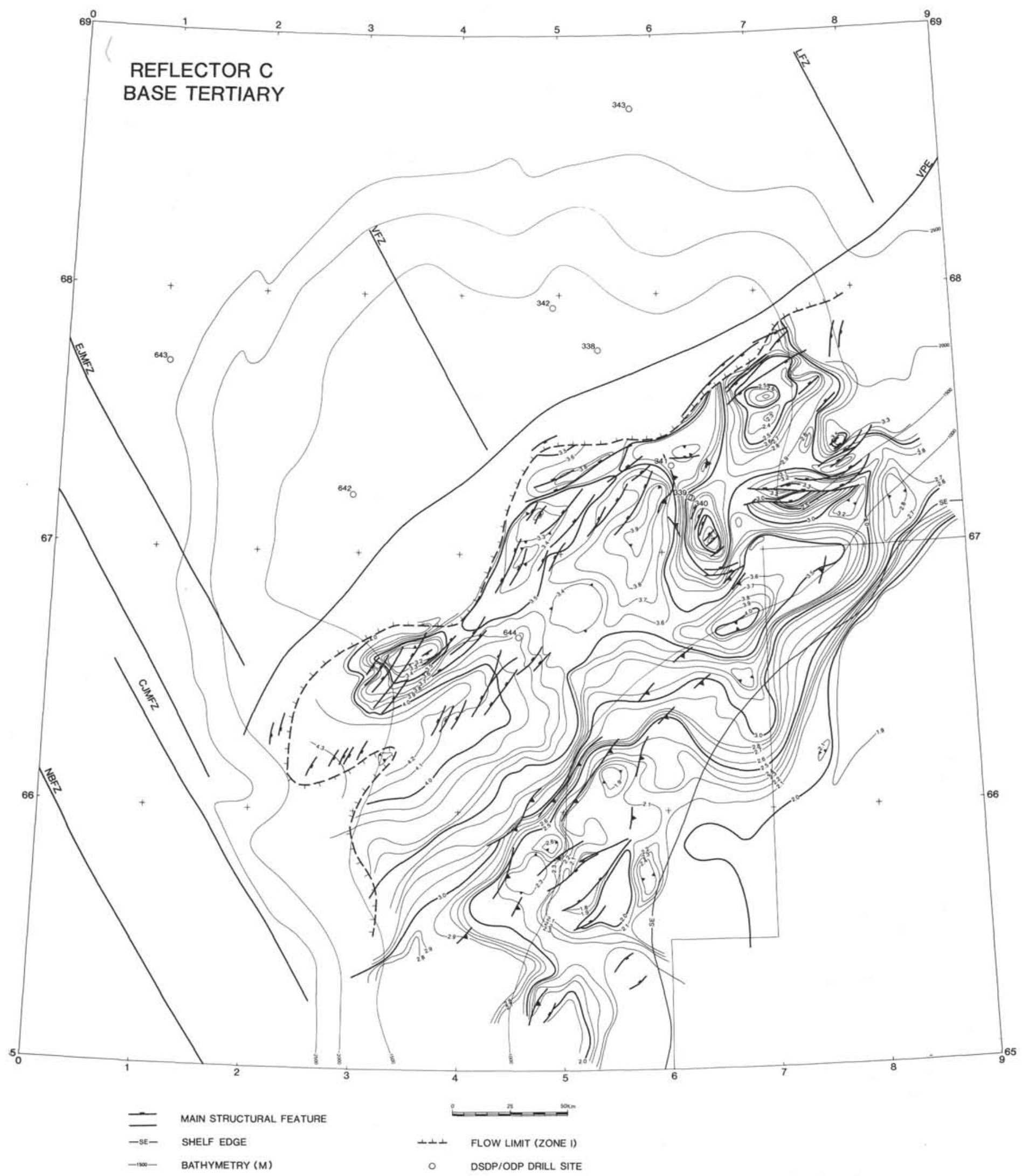

Figure 7. Isochrone and structural map at the base-Tertiary level, reflector C. Contour interval: $0.1 \mathrm{~s}$. Abbreviations as in Figure 2. 


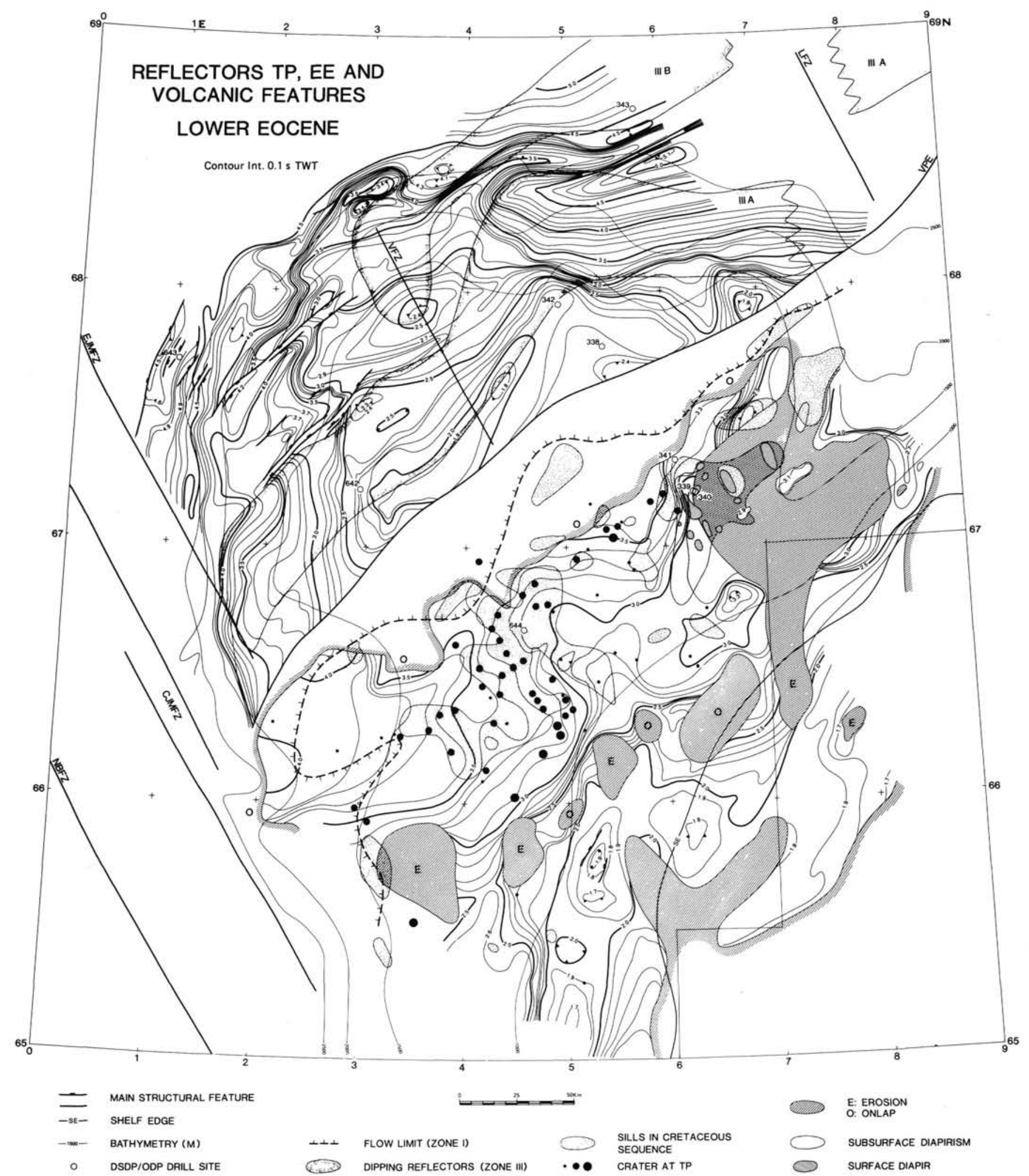

Figure 8. Isochrone map reflectors TP, EE, and the oceanic crust. Although the ages might vary slightly within the map, we believe the contours reflect a lower Eocene surface. The map includes the distribution of volcanic features, including the crustal zonation of Skogseid and Eldholm (1987) seaward of the Vøring Plateau Escarpment. Abbreviations as in Figure 2. 

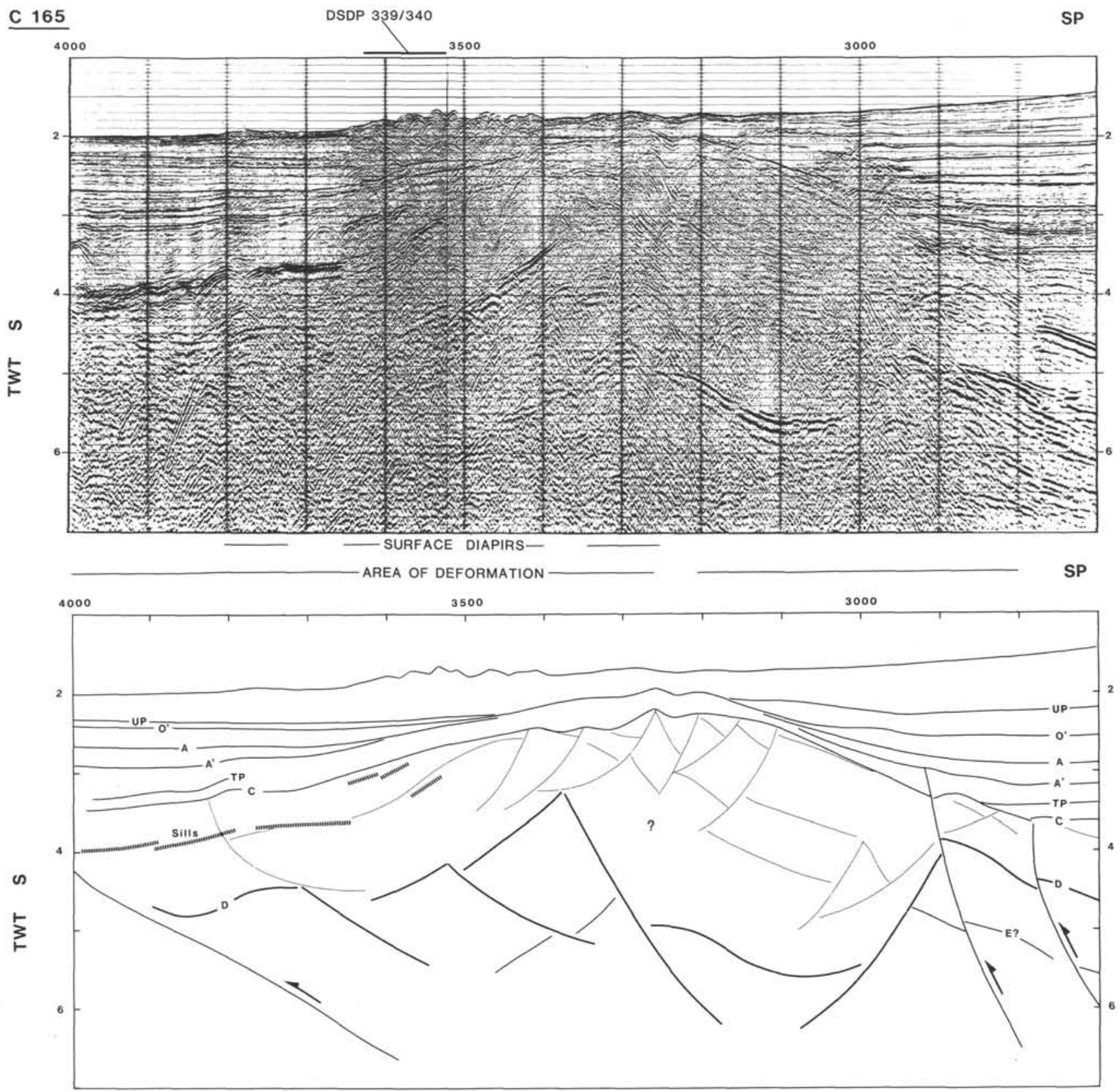

Figure 9. Seismic profile C-165 illustrating normal and reverse faulting, doming and diapirism across the southern Fleina Rift. Location given in Figure 3. For reflector nomenclature see text. The approximate location of DSDP Leg 38 Sites 339 and 340, drilled within the diapir province slightly to the side of the profile, is indicated.

ever, the unconformity gradually loses distinction and the overlying sediments thin towards the western basin where the base Pliocene and upper Pliocene reflectors merge. The latter horizon is mapped over the entire margin.

\section{ODP/DSDP Site Correlation}

The principal drilling results (Eldholm et al., this volume) have been correlated with the most adjacent MCS profiles. All four drill sites in the Vøring Basin (Fig. 3) have limited penetration, the maximum $456 \mathrm{~m}$ at DSDP Site 341 . The cored depths have been converted to reflection times using a velocity of 1.6 $\mathrm{km} / \mathrm{s}$.

ODP Site 644 was drilled in a region of well-defined horizontal layers (Fig. 14). Reflector UP corresponds to the base of the glacial sequence at the transition between lithologic Units I and II in the upper Pliocene. At this level there is a typical decrease in sediment bulk density (Eldholm, Thiede, Taylor et al., 1987). At both Sites 642 and 643, UP marks a hiatus which is not present at Site 644. The band of reflectors above UP is associated with the large concentrations of biogenic gas between 50 and $140 \mathrm{mbsf}$.

DSDP sites 339 and 340 were drilled in the diapir province over the Vema Dome, each reaching just below $100 \mathrm{~m}$ total depth. Pliocene-Pleistocene sandy muds and diatom oozes over lower to middle Oligocene diatom oozes and muds were recovered from Site 339, located in a saddle between two diapirs. At Site 340 , on top of a diapir rising $150 \mathrm{~m}$ above the sea floor, homogeneous diatom ooze of mixed upper and middle Eocene age 


\section{NOR-JM-9}

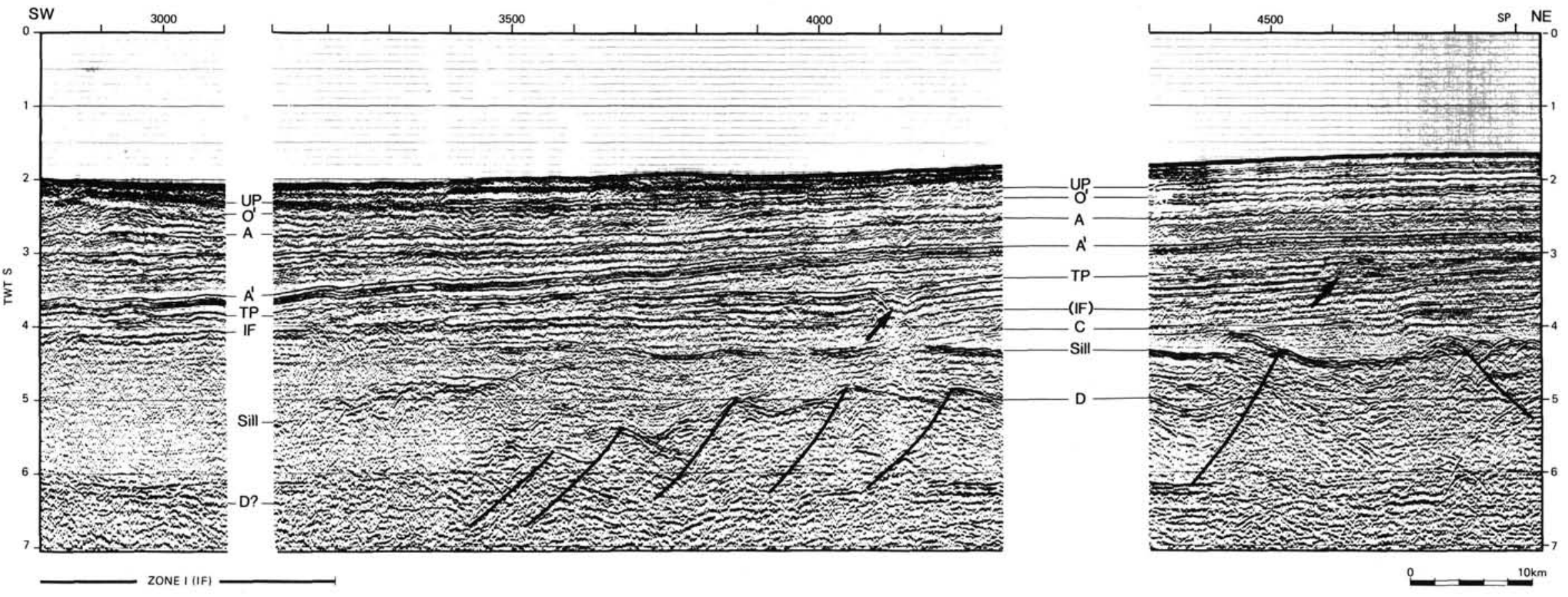

Figure 10. Seismic section illustrating the various volcanic signatures and the stratigraphic relations between reflectors C (base Tertiary), IF (inner flow) and TP (lower Eocene). The arrows indicate probable fissure vents (craters) at the level of reflector TP. Location given in Figure 3. For reflector nomenclature see text. 


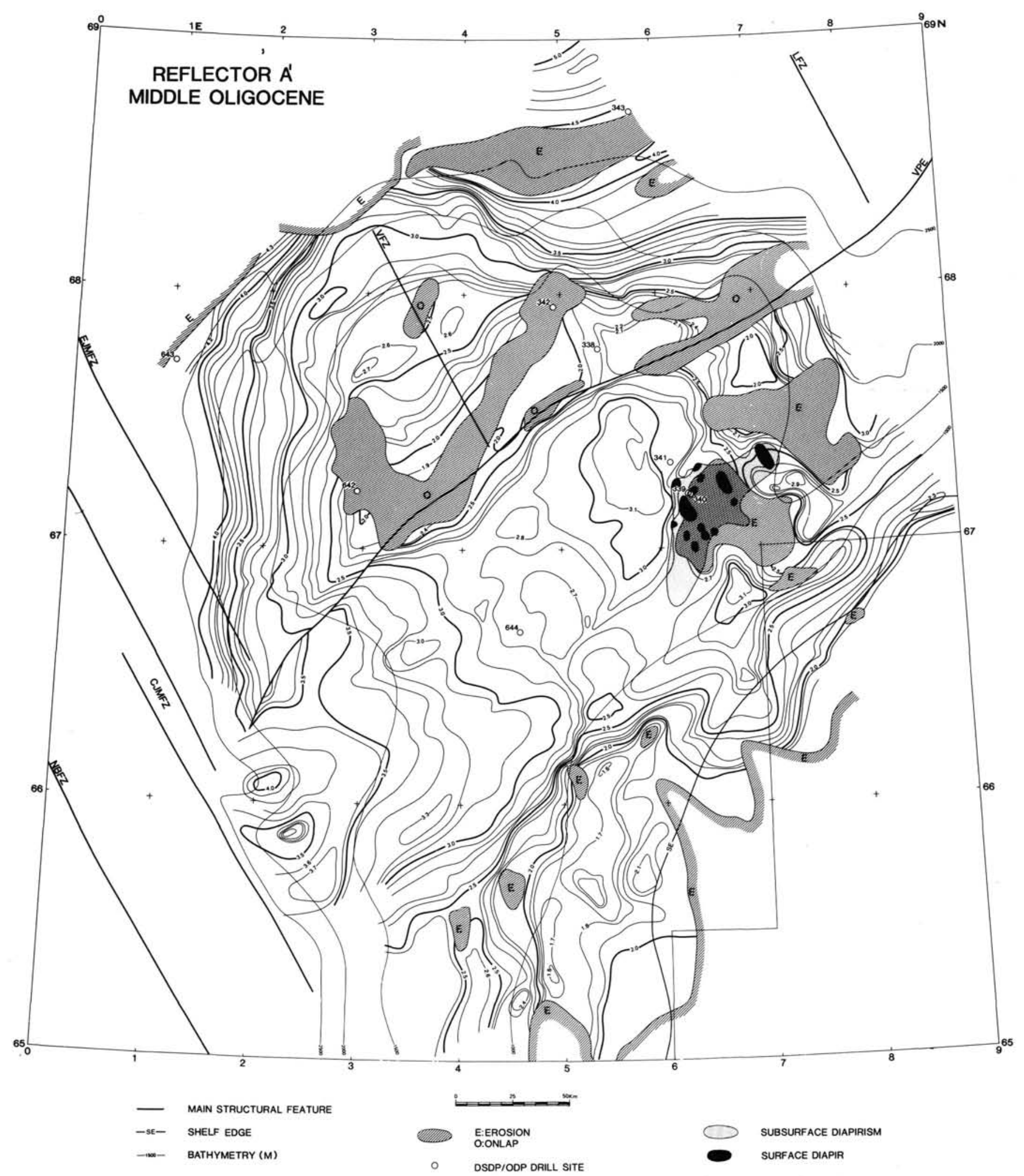

Figure 11. Isochrone map of reflector $\mathbf{A}^{\prime}$, middle Oligocene. Contour interval 0.1 s. Abbreviations as in Figure 2. 


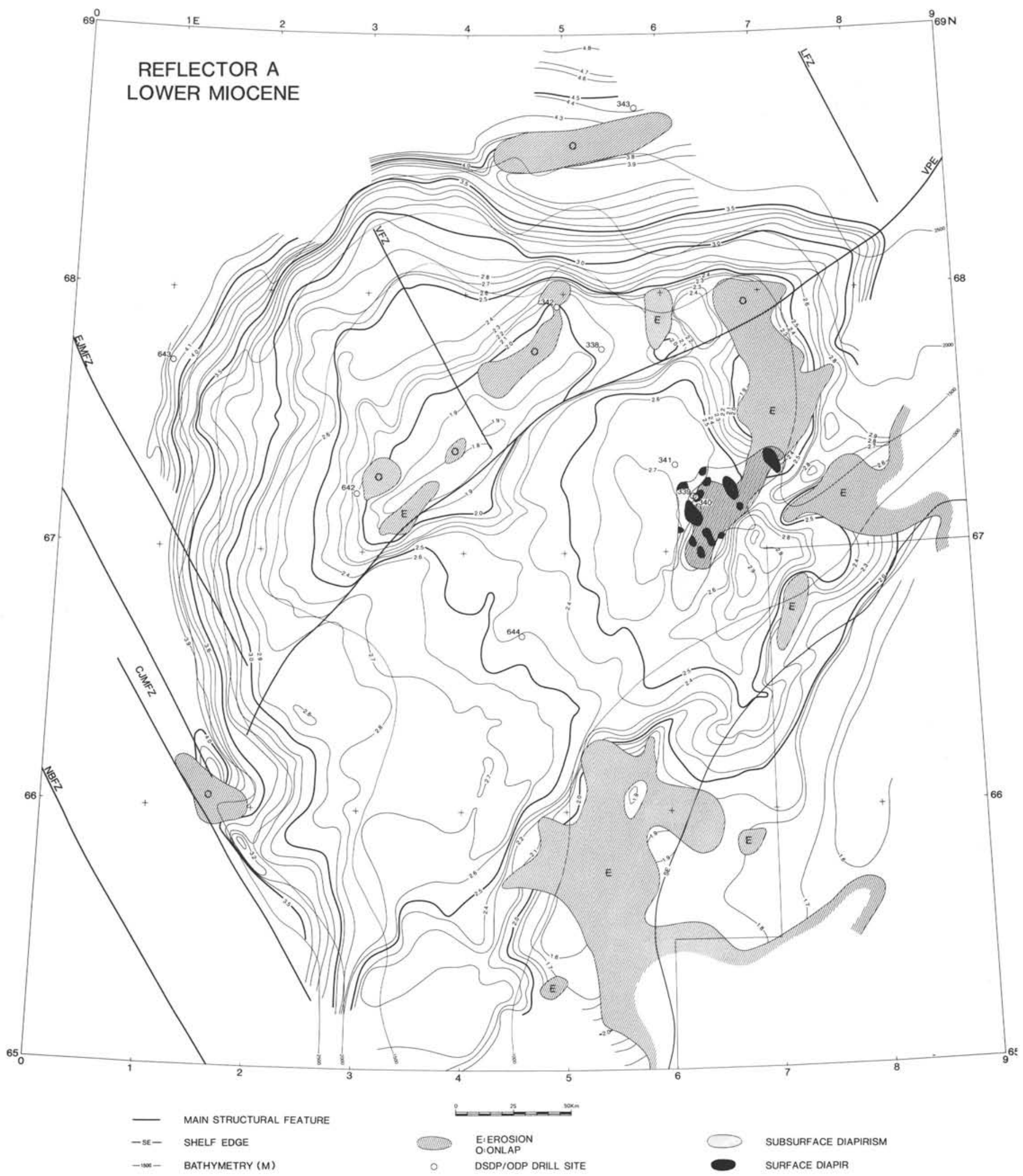

Figure 12. Isochrone map of reflector A, lower Miocene. Contour interval $0.1 \mathrm{~s}$. Abbreviations as in Figure 2. 


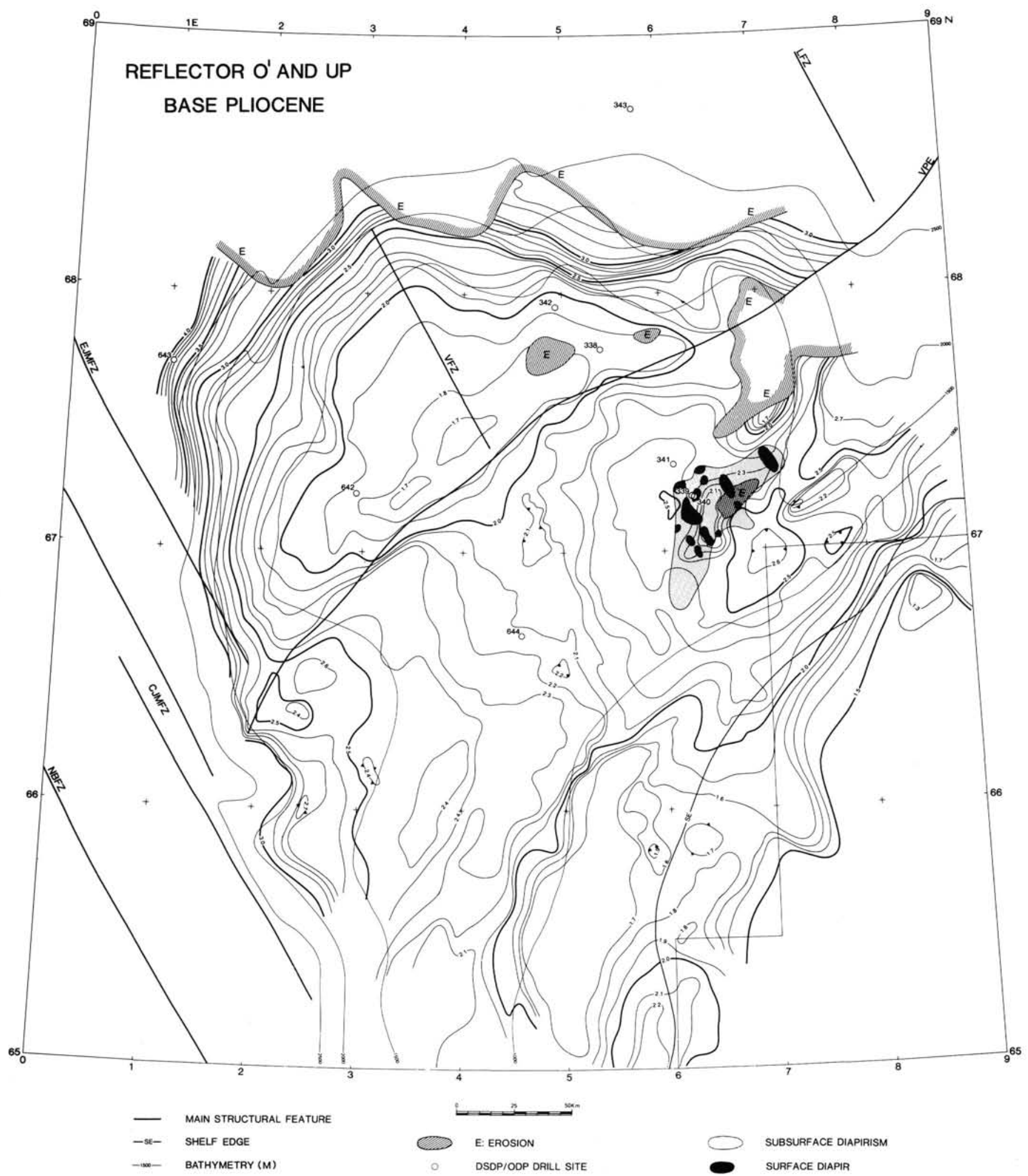

Figure 13. Isochrone map of reflector $\mathrm{O}^{\prime}$, base-Pliocene in the Vøring Basin and reflector UP, upper Pliocene seaward of the Vøring Plateau Escarpment. Contour interval $0.1 \mathrm{~s}$. Abbreviations as in Figure 2. 

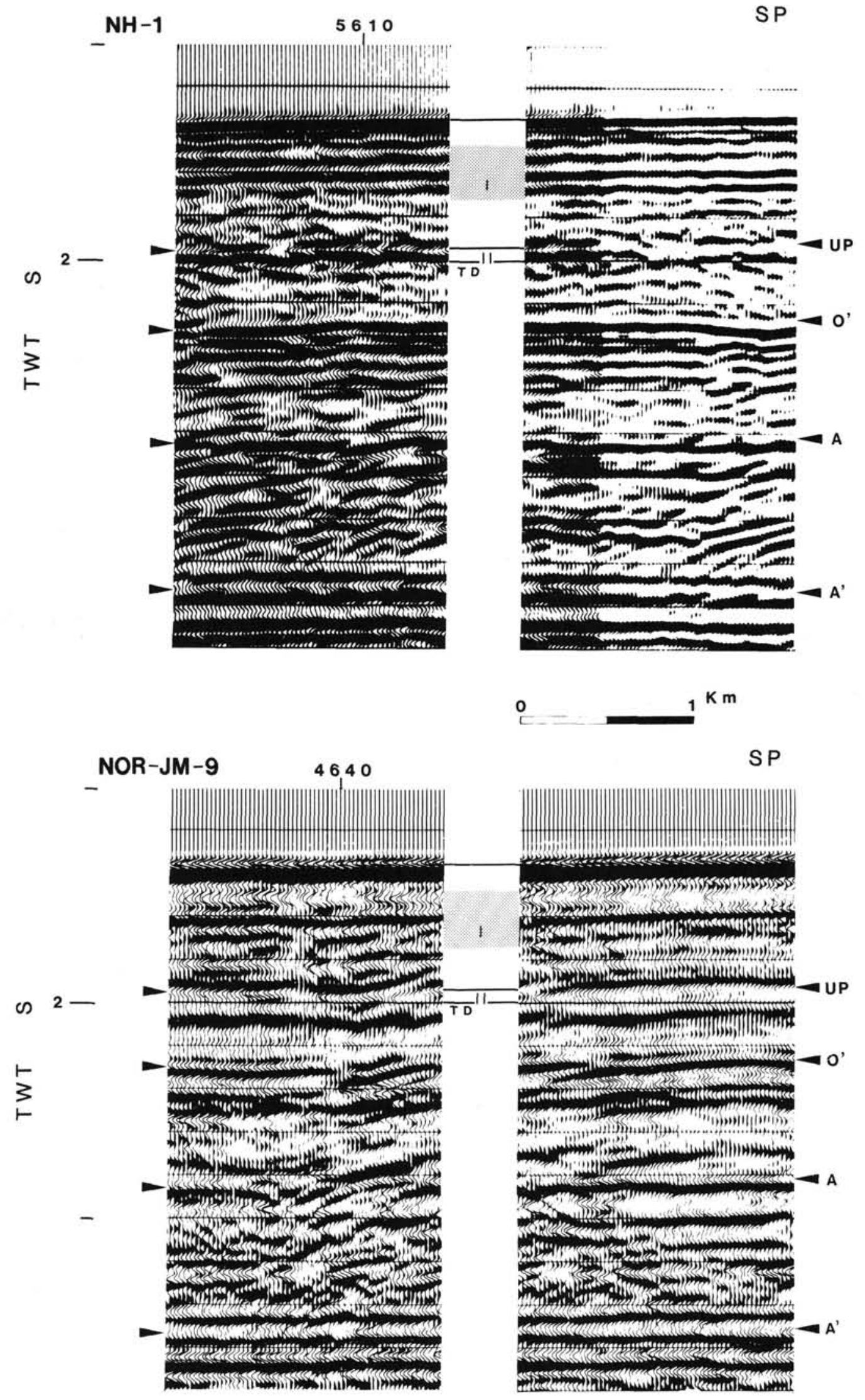

Figure 14. Multichannel seismic profiles NH-1 and NOR-JM-9 (time sections) at ODP Site 644. Location given in Figure 3. Lithological units (center) from Eldholm, Thiede, Taylor et al. (1987). Region of main biogenic gas concentrations indicated by shading. UP: upper Pliocene, $\mathrm{O}^{\prime}$ : base-Pliocene, $\mathrm{A}$ : lower Miocene, $\mathrm{A}^{\prime}$ : middle Oligocene, TD: total depth. 
below a 10-m veneer of Pleistocene mud was sampled (Talwani, Udintsev et al., 1976). No MCS line crosses the sites but the structural position is shown in Figure 9.

DSDP Site 341, which was drilled about $17 \mathrm{~km}$ northwest of the diapir field in undisturbed Neogene sediments, terminated in middle Miocene mudstones (Fig. 15). Reflector $\mathrm{O}^{\prime}$ corresponds to the hiatus near the top of lithological Unit III, separating middle Miocene calcareous diatomite and diatomaceous mudstone from the Pliocene-Pleistocene muds, sandy muds, and calcareous oozes of lithological Unit II. Reflector UP originates from within Unit II.

\section{OUTER VØRING PLATEAU SEDIMENTS}

The most prominent seismic horizon seaward of the Vøring Plateau Escarpment is the high-amplitude, smooth acoustic basement reflector EE originating at the interface between the Cenozoic sediments and the underlying flow basalts. At the outer flank of the plateau, reflector EE changes into irregular oceanic basement. The basement depth and character are shown in Figure 8. Here, we first describe the sediments above reflector EE and oceanic basement, later returning to the underlying volcanic series at the marginal high and the extrusives and intrusive rocks in the Vøring Basin.

The early single-channel seismic profiles demonstrated that the sedimentary sequence could be separated in an upper and a lower unit separated by a distinct regional reflector (Talwani and Eldholm, 1972; Eldholm and Windisch, 1974). Caston (1976) gave it a middle Oligocene age, primarily by correlation to DSDP Site 338. However, he pointed out that the dating was ambiguous because several closely spaced reflectors, ranging in age from early Eocene to Oligocene/Miocene, were drilled at the site. Later investigators have accepted the interpretation, and related the unconformable reflector to the middle Oligocene global fall in sea level (Hinz et al., 1984; Mutter, 1984). Using ties to the continental shelf Skogseid (1983) and Skogseid and Eldholm (1987) suggested that the unconformity actually corresponded to the lower Miocene level (reflector A) of Rønnevik et al. (1979) and Jørgensen and Navrestad (1981). This interpretation was supported by the Leg 104 results (Eldholm, Thiede, Taylor et al., 1987).

The present interpretation started with a transect of three MCS profiles (BGR-1, NH-1, and NOR-JM-10, Fig. 3) located over, or very close to, ODP Sites 642 and 643 . By correlating seismic and drilling results and tying the reflectors across the escarpment, we obtained a stratigraphy consistent with that in the Vøring Basin. Then, the transect horizons were extended over the entire outer plateau and tied to the DSDP sites using both MCS and single-channel lines.

Reflector A separates a lower sequence of relatively regular depositional patterns from a more irregular and locally disturbed upper sedimentary sequence (Fig. 16). It is also the uppermost unconformity that reflects erosion of large areas of the marginal high (Fig. 12); probably at relatively shallow water depths, causing redeposition of a considerable amount of volcanic and volcaniclastic material.

A primary result of this interpretation is the understanding that the region west of the Vøring Plateau Escarpment has been relatively high during much of the Cenozoic time, governing sediment deposition in the Vøring Basin as well as in the growing oceanic basins (Fig. 16). The sediments above reflector A
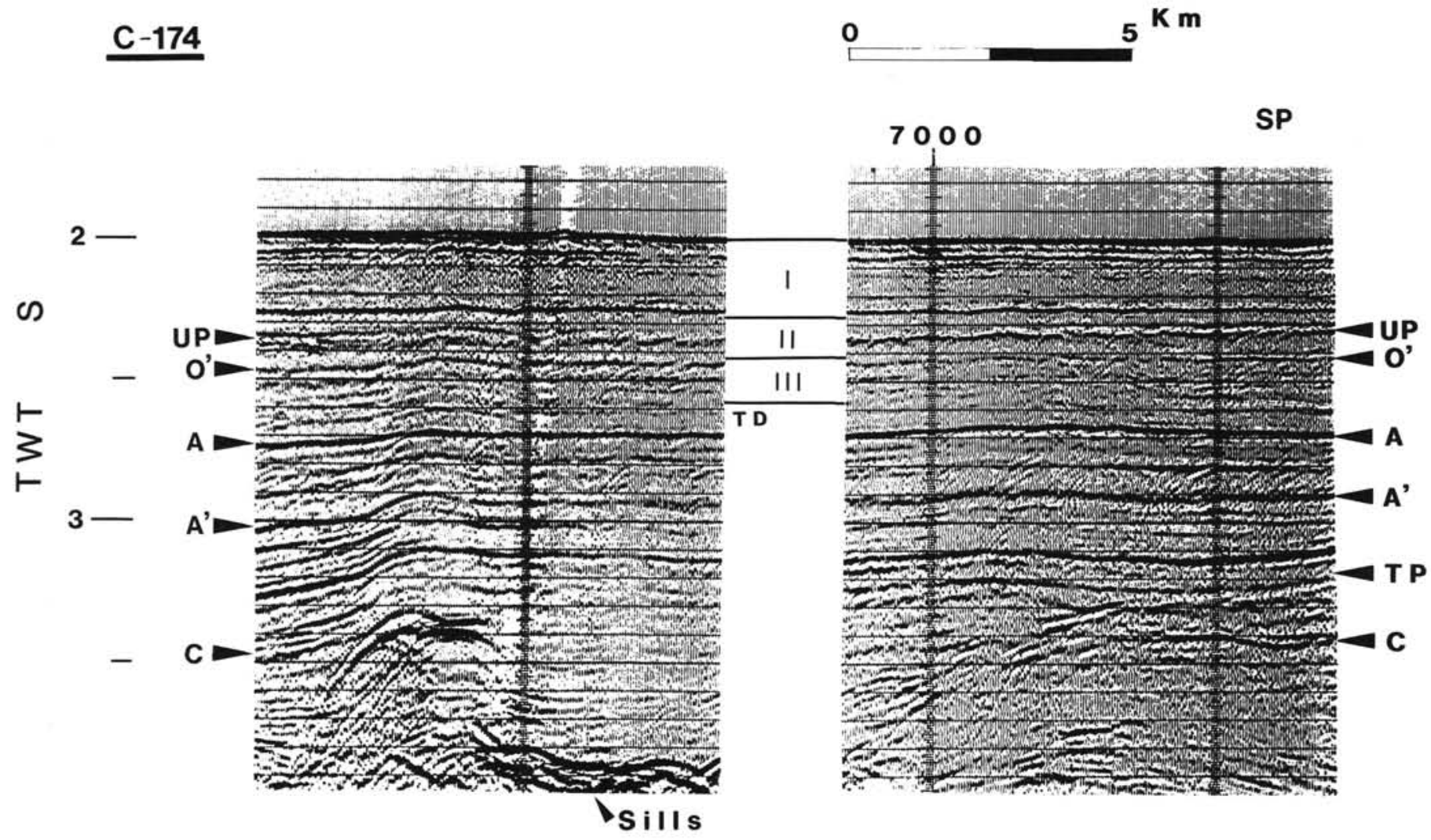

Figure 15. Multichannel seismic profile C-174 (time section) near DSDP Site 341. Location as in Figure 3. Lithological units (center) from Talwani, Udintsev et al. (1976). UP: upper Pliocene, $\mathrm{O}^{\prime}$ : base-Pliocene, A: lower Miocene, A': middle Oligocene, TP: lower Eocene tuff, C: base-Tertiary, TD: total depth. 

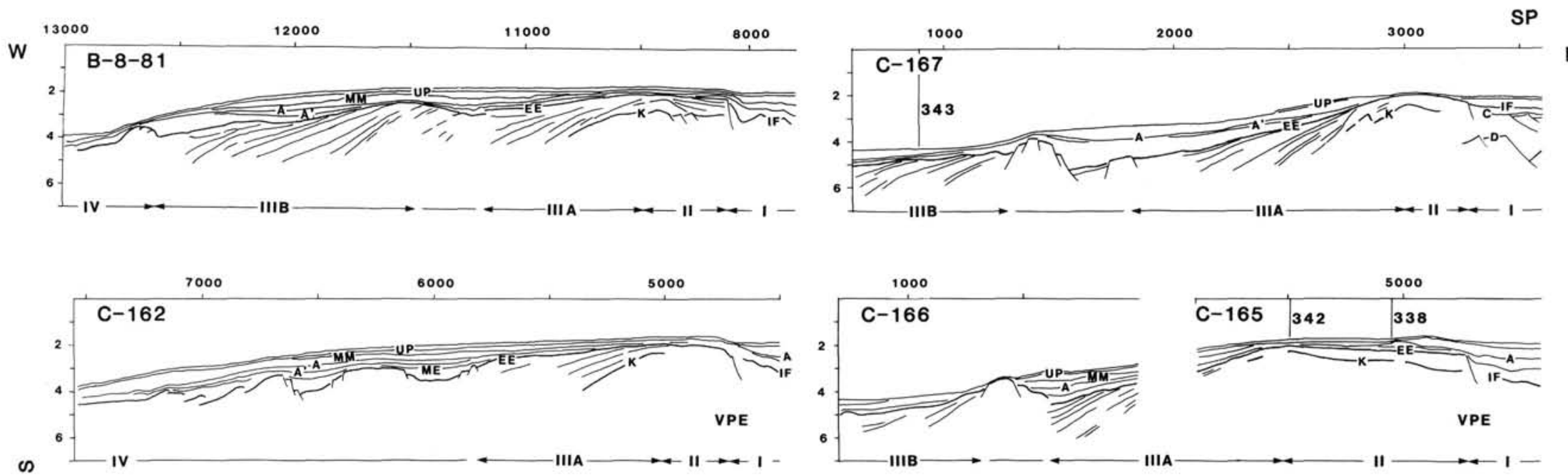

$\xi$
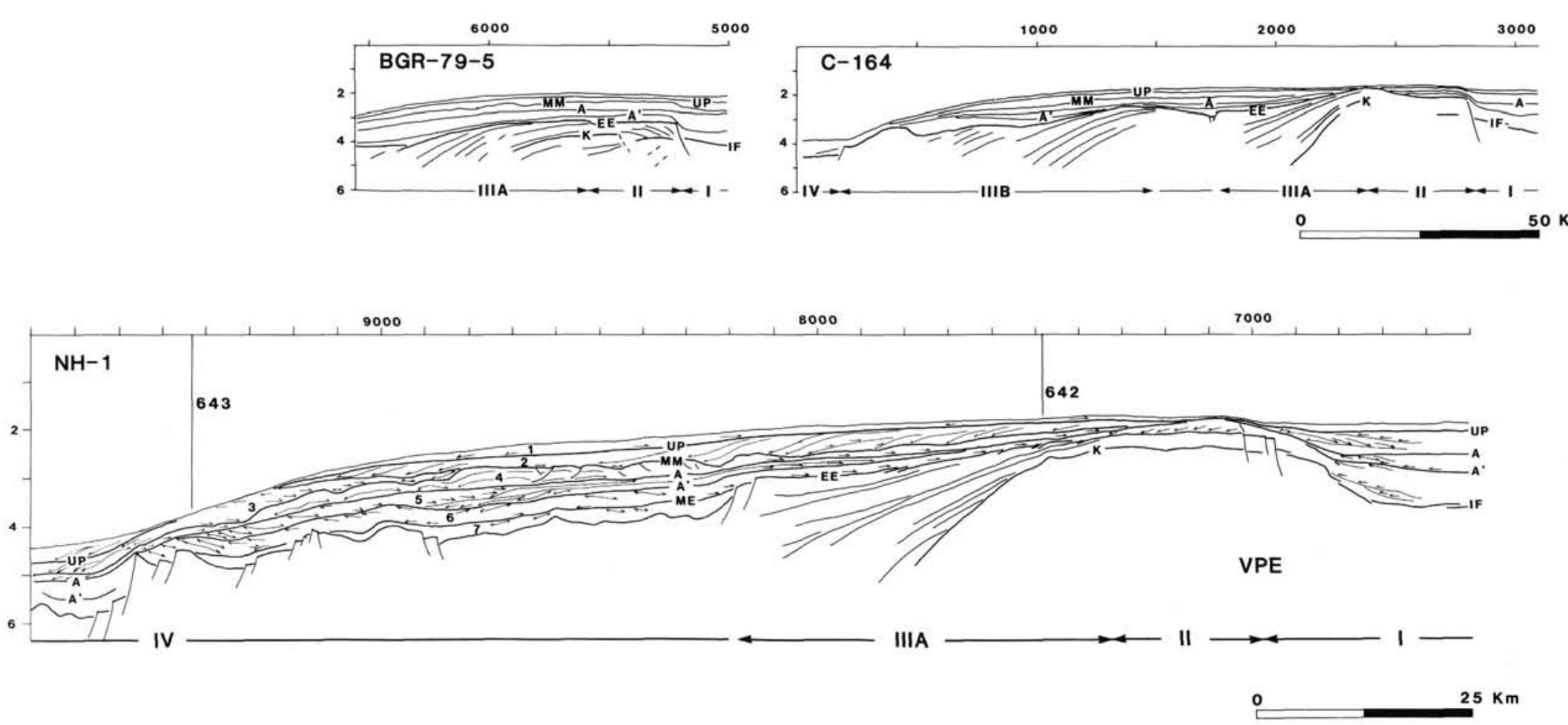

Figure 16. Interpreted seismic sections with ODP/DSDP drill sites at the outer Vøring Plateau. At bottom is profile NH-1 (note the expanded vertical scale), illustrating the main depositional sequences (1-7) described in the text. The volcanic zonation (I-IV) of Skogseid and Eldholm (1987) is shown below the profiles. Locations given in Figure 3. VPE: Vøring Plateau Escarpment. For reflector nomenclature, see text. 
appear to have been deposited in deeper waters, but still reveal a depositional configuration that is not unlike that of a subsiding margin in more coastal environments. In describing the sequences, we have therefore applied some of the terms introduced by Vail et al. (1977), now commonly used in sequence stratigraphy.

\section{ODP/DSDP Site Correlation}

Site 642 confirms that reflector EE corresponds to the top of the flow basalts. Reflector A is correlated with the unconformity between lithologic Units III and IV at 277.6 mbsf (Fig. 17) where there is a a clear change in acoustic impedance (Hempel et al., this volume). The overlying biogenic sediments are of lower Miocene age, and Figures 12 and 18 show that large parts of the pre-lower Miocene sequence is absent in areas of shallowing EE.

In the Neogene section there is good correlation of reflectors and lithology. The uppermost, irregular reflector (UP, Fig. 17) is related to the change from glacial/interglacial sandy muds to predominantly nannofossil oozes at the boundary between lithologic Units I and II. Reflector MM at about 200 mbsf appears to reflect a change from siliceous muds to oozes within lithologic Unit III at the lower to middle Miocene transition.

The correlation in Fig. 17 results in a low average velocity, approximately $1.60 \mathrm{~km} / \mathrm{s}$, for the section above EE. Due to the small thickness of the A-EE sequence it is not meaningful to calculate a separate interval velocity for the pre-Miocene sediments. We stress that these estimates are uncertain and that precise values require seismic modeling, but available work at Site 642 (Hinz et al., 1987; Theilen et al., 1987; Hempel et al., this volume) has not addressed this problem. Low seismic velocities were also inferred from the sonic log and measured in the recovered cores (Eldholm, Thiede, Taylor et al., 1987).

Site 643 is located slightly off profile NH-1, and reached basement rocks at a shallower depth than anticipated. In fact, the total depth is close to the top of the sidesweep in Figure 19. At the actual site, a basement reflector at this depth was confirmed by the much poorer quality profile NOR-JM-10 (Fig. 19). Site 643 did not sample solid basement rocks due to severe infilling of the hole near the total depth. However, the rock assemblages and tholeiitic basalt fragments sampled at the bottom of the hole are interpreted as a basal sequence resting on oceanic basement (Eldholm, Thiede, Taylor et al., 1987). This site also yields low sediment velocities. Values of 1.57 and 1.67 $\mathrm{km} / \mathrm{s}$ are calculated above and below A respectively, corresponding to velocities measured in the cores (Eldholm, Thiede, Taylor et al., 1987).

Reflector UP (Fig. 19) correlates with the upper Pliocene to Pleistocene hiatus between lithological Units I and II, and reflector MM originates from within the diatom oozes of lithological Unit III in sediments dated to about $16 \mathrm{Ma}$ (Goll, this volume). Local deviations in velocity and porosity values are measured at this level (Eldholm, Thiede, Taylor et al., 1987). Figures 16 and 19 show that the lower Miocene unconformity truncates the beds below. It is associated with the transition from lithological Units III to IV that marks a major change in consolidation history. In particular, Unit IV reveals an unusually high degree of consolidation with complex diagenetic alterations below about 300 mbsf. At this level the physical properties reach new and stable values (Pittenger et al., this volume). We correlate reflector A with this change in the uppermost part of lithologic Unit IV.

The approximately $100 \mathrm{~m}$ of lower Miocene sediments below reflector A correspond approximately to the lowermost Miocene dinocyst $A$. granosa Zone (Manum et al., this volume). Thus, the lower Miocene unconformity covers a much shorter time span than at Site 642. The change from lithological Unit IV to $\mathrm{V}$ at the Oligocene/Miocene boundary correlates with a weak reflector directly overlying a better-developed horizon (TO and $A^{\prime}$, Fig. 19). The latter, which is still better developed farther east and trunctated by $A$ just west of Site 643 , is dated as middle Oligocene from the dinocyst zonations of Manum et al. (this volume). Their Oligocene stratigraphy is also compatible with an unconformity at this time. Finally, reflector ME might be associated with the upper to upper middle-Eocene hiatus proposed by Manum et al. (this volume). On the other hand, Kaminski (1987) proposed that the sediments below reflector A are predominantly Oligocene with a $50-\mathrm{m}$ basal section of lower Eocene age. This does not change the reflector ages in a major way, but we consider the age of the pre-lower Miocene sedimentary sequences uncertain.

By tying the regional seismic makers to DSDP sites 338,342 , and 343 (Fig. 16), we obtain a reasonable correspondence with lithology and biostratigraphic ages (Talwani, Udintsev, et al., 1976). Unfortunately, Site 338 (Fig. 20) was drilled in an area where the Miocene and upper Oligocene section is severely disturbed, making a direct seismic correlation difficult (Caston, 1976). The sediments near the site show evidence of probable current scouring and erosion leaving redeposited drifts and mounds. In addition, Caston (1976) documented diapirism, reaching almost to the sea floor, originating from the sequence between the middle Oligocene and lower Miocene reflectors.

The seismic data document recent erosion and downslope mass movements at the lower outer flank of the plateau. In particular, the pronounced middle Eocene to Pliocene hiatus encompassing the lower Miocene unconformity at Site 343 (Fig. 21) suggests that erosion might have been active also prior to the Pliocene.

\section{Post-lower Miocene Sediments}

Four regional sequences characterize the different depositional regimes above the lower Miocene unconformity (Figs. 16, 18). The upper, Sequence 1 between the sea floor and reflector UP, consists of Pleistocene-upper Pliocene glacial deposits. The cores reveal glacial-interglacial cycles of alternating dark, relatively carbonate-poor, and light, carbonate-rich layers of mud, sandy mud, and sandy calcareous mud (Eldholm, Thiede, Taylor et al., 1987). The sediments are eroded at the sea floor, both at the highest part of the plateau west of the escarpment and at the slope towards the Lofoten Basin (Fig. 13). The reflection patterns show a general onlap in the eastern direction and a seaward downlap onto reflector UP to the west.

The next unit, between reflectors UP and MM, has been divided into two depositional sequences, 2 and 3 , by a sequence boundary at the upper flank of the plateau $(\mathrm{NH}-1$ shotpoints $8825-9225$, Fig. 16). This boundary is traced from the change in depositional patterns only, whereas reflector $\mathrm{MM}$ at the base of sequences is a strongly undulating horizon. Sequence 2 is characterized by westward progradation. The beds toplap the upper Pliocene reflector and downlap onto the lower sequence boundaries westward (Fig. 16). The clinoforms are steepest in the east, where we recognize several subsequences, becoming gradually gentler at the western plateau. Site 642 results reveal that the sediments are biogenic siliceous muds and oozes with some calcareous material in the uppermost part. Site 643 recovered similar sediments from Sequence 3. Here, the beds onlap the lower sequence boundary in the east, changing to downlap farther west.

Sequence 4, between reflectors MM and A, is particularly irregular and disturbed (Figs. 16 and 18). The top of this sequence is truncated and shows local channel erosion, and the upper part progrades westward, whereas the lower part onlaps the lower Miocene unconformity toward the east. The entire sequence, consisting of biogenic diatom muds and oozes, appears to be deformed by settling and differential compaction (Fig. 

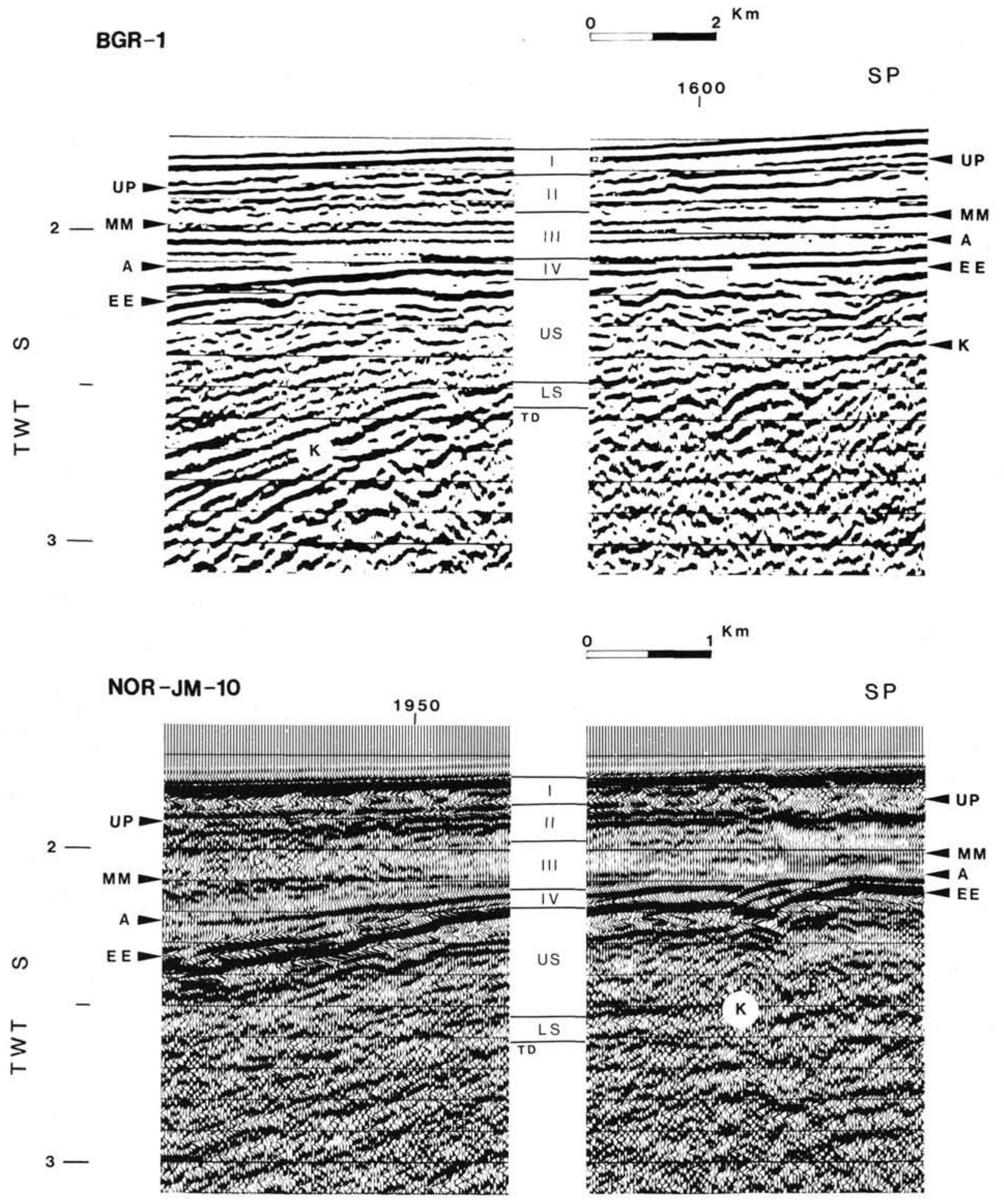

Figure 17. Multichannel seismic profiles BGR-1 (migrated time section) and NOR-JM-10 (time section) in the vicinity of Site 642 . Location given in Figure 3. Lithologic units (center) from Eldholm, Thiede, Taylor et al. (1987). UP: upper Pliocene, MM: middle Miocene, A: lower Miocene, EE: lower Eocene flows. Reflector K marks the change from UP: upper volcanic series to LS: lower volcanic series. TD: total depth.

18). The deformation is only observed above reflector A, however.

In terms of sediment deposition, we interpret the basal part of Sequence 4 to represent a period of gradually decreasing sedimentation rates relative to subsidence, causing the landward onlap on reflector A. This period was followed by a phase of in- creased sediment input, keeping pace with subsidence and causing a seaward progradation accompanied by local erosion and redeposition. At Site 642 this depositional change might be reflected in the abnormal decrease in bulk density and porosity with depth and high water content in lithological Unit III. More importantly, the undrained shear-strength measurements show 
$\underline{\mathrm{NH}-1}$

8600

8500

8400

8300

8200

SP

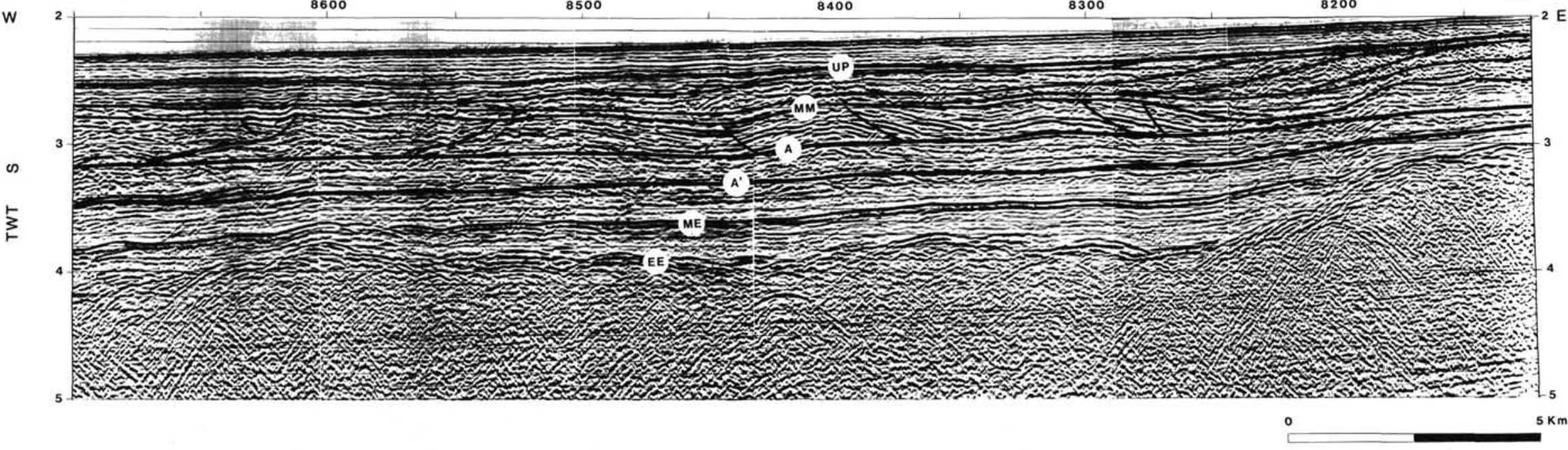

Figure 18. Seismic section showing the Cenozoic stratigraphy and post-Oligocene deformation at the outer Vøring Plateau. Location given in Figure 3. UP: upper Pliocene, MM: middle Miocene, A: lower Miocene, $\mathrm{A}^{\prime}$ : middle Oligocene, ME: middle Eocene, EE: lower Eocene flow basalts. 

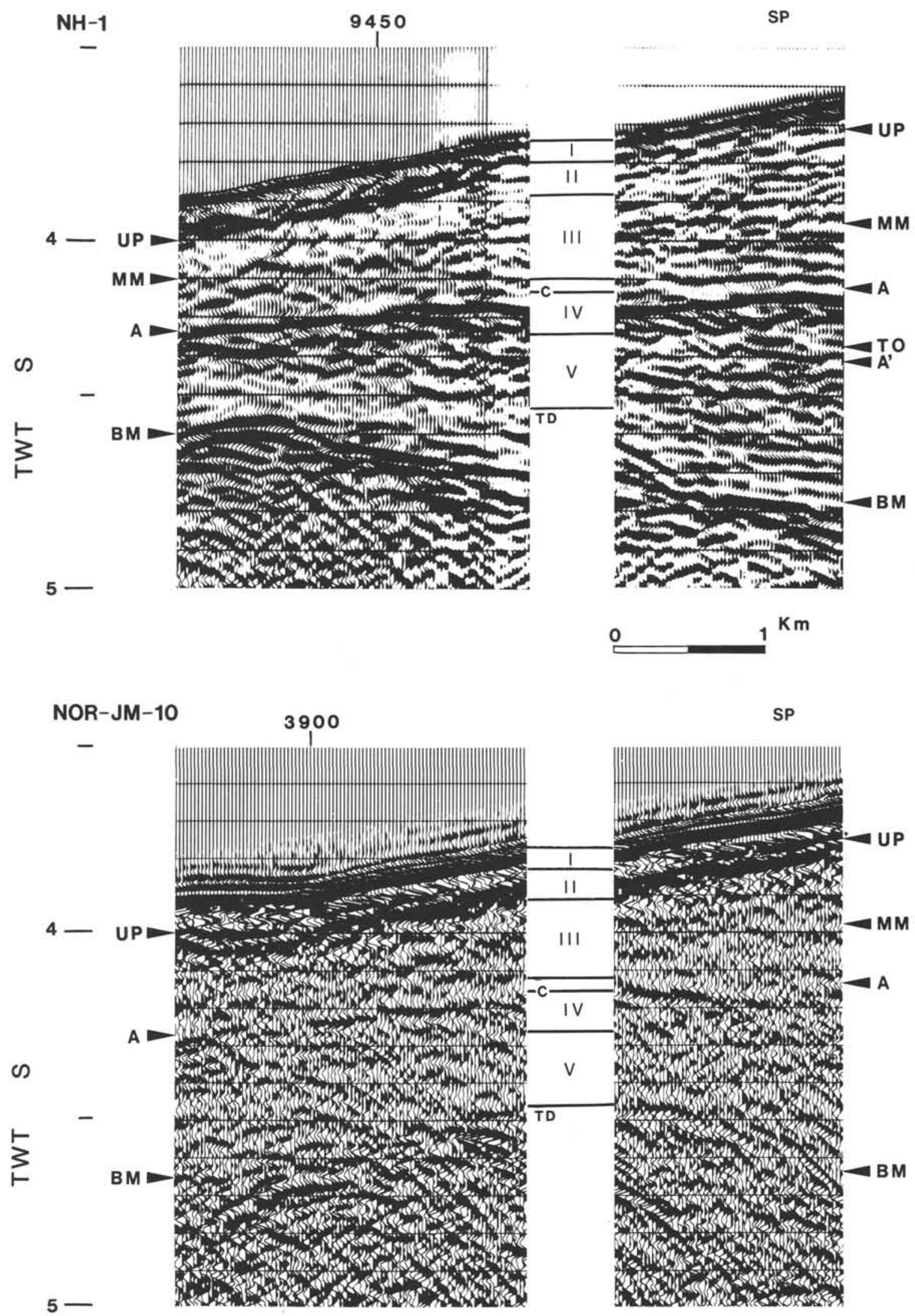

Figure 19. Multichannel seismic profiles NH-1 and NOR-JM-10 (time sections) in the vicinity of Site 643. Location given in Figure 3. Lithologic units (center) from Eldholm, Thiede, Taylor et al. (1987); C marks the top of the over-consolidated sediments. UP: upper Pliocene, MM: middle Miocene, A: lower Miocene, TO: top-Oligocene, $A^{\prime}$ : middle Oligocene, BM: oceanic basement, TD: total depth. 


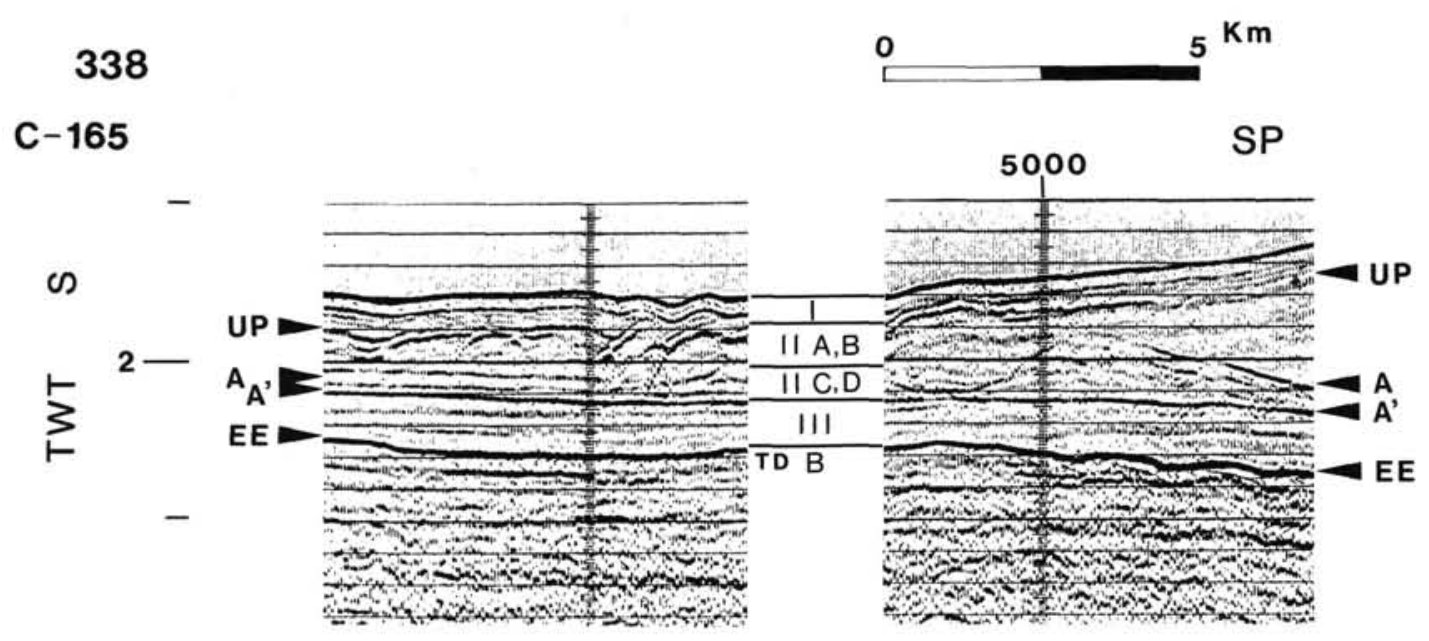

\section{2}

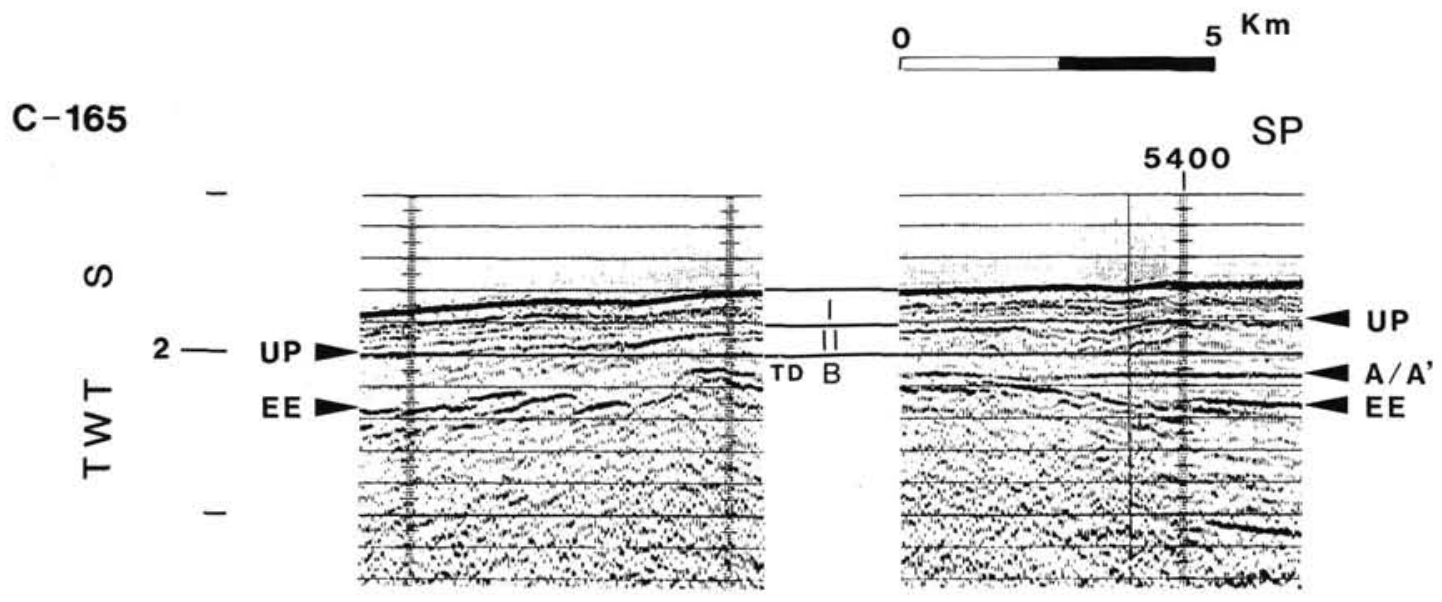

Figure 20. Multichannel seismic profile C-165 (time section) near DSDP sites 338 and 342. Location given in Figure 3. Note that the sites are located slightly off profile C-165. Lithological units (center) from Talwani, Udintsev et al. (1976). UP: upper Pliocene, A: lower Miocene, A' : middle Oligocene, EE: lower Eocene flow basalts, TD: total depth.

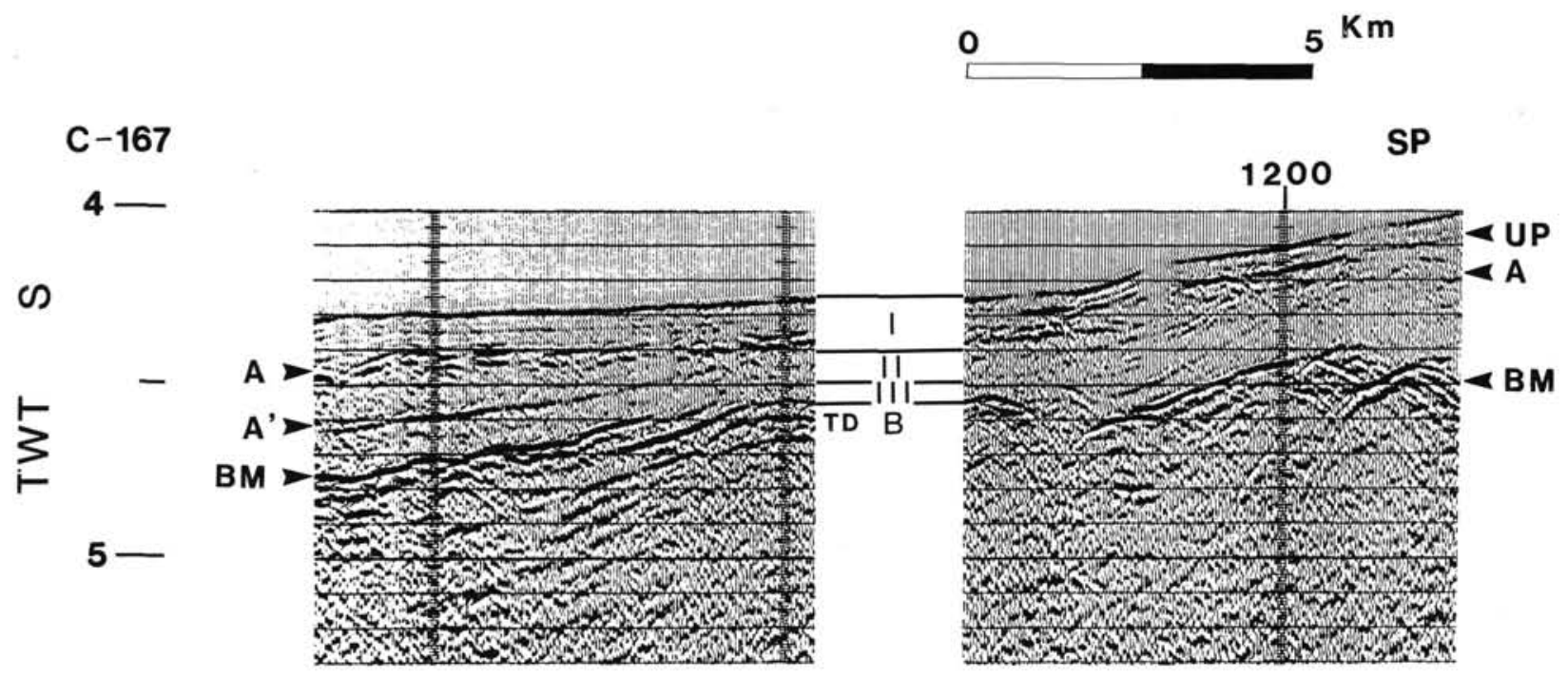

Figure 21. Multichannel seismic profile C-167 (time section) near DSDP Site 343. Location given Fig. 3. Lithologic units (center) from Talwani, Udintsev et al. (1976). UP: upper Pliocene, A: lower Miocene, A' : middle Oligocene, BM: oceanic basement, TD: total depth. 
a normal consolidation history in Sequences 1 and 2, whereas Sequence 4 is clearly undercompensated, possibly associated with diagenetic processes acting in the smectite and ash fractions. Similar, although slightly less pronounced, trends are revealed by the physical properties measurements in Sequence 4 at Site 643 (Eldholm, Thiede, Taylor et al., 1987; Pittenger, this volume). We believe these conditions are responsible for the internal deformation and mass movements within Sequence 4 as well as the slumping in front of the prograding shelf edge (Fig. 16). Toward the middle Miocene the sediment flux again decreased and the outbuilding ceased. The sea floor became exposed to erosion over most of the outer plateau, resulting in a system of current channels transporting sediments to the west and constructing the deep marine fan/lowstand wedge in Sequence 3.

Subsequent to Sequence 3 formation a new pulse of sediment input from the elevated northern plateau and the Vema Dome moved the depocenter to the east. Sediment supply kept pace with subsidence and Sequence 2 prograded westward. Finally, Sequence 1 was laid down under quiet conditions. Significant erosion, probably by contour currents, took place on the steep outer flank during deposition of both Sequences 1 and 2 and is still active.

\section{Pre-lower Miocene Sediments}

The sediments between the lower Miocene unconformity and the acoustic basement (Fig. 22) form three main depositional sequences separated by the middle Oligocene unconformity and the middle Eocene reflector. The latter horizon is only mapped south of the Vøring Fracture Zone.

The lowermost Sequence 7 is only observed below reflector ME within a fault controlled local basement depression at the southwestern marginal high. The depression is bounded to the east by a steep fault zone at the western termination of the seaward-dipping reflector wedge (Fig. 16). The fault zone also marks the change from a smooth reflector EE to an irregular oceanic basement surface, near the Zone III/IV transition (Fig. 8 ). Reflector ME has a distinct character and is easily recognized despite few tie lines, onlapping the basement highs on either side of the depression. Site 643 results indicate that Sequence 7 contains zeolitic mudstones and altered volcaniclastic sediments, and we infer a middle Eocene age for ME. We also note that the sequence overlies the oldest oceanic crust at the Vøring Plateau (Skogseid and Eldholm, 1987). Absence of faulting in the sediments indicates that the structuring occurred prior to the deposition of Sequence 7, possibly associated with the westward shift in the plate boundary just prior to anomaly 23 time (Hagevang et al., 1983).

The basement depression is also reflected in the depositional pattern of the two subsequent sequences, 5 and 6 , bounded by reflectors $\mathrm{A}-\mathrm{A}^{\prime}$ and $\mathrm{A}^{\prime}-\mathrm{ME}$, respectively. Both sequences are eroded over the flanks of the depression with redeposition in the central part. There is outbuilding from the east, forming numerous subsequences of prograding wedges interfingering with transgressive units and associated onlapping sequences (Fig. 16). In the western part, on the other hand, the prograding clinoforms are steeper and of limited extent, indicating a local and less significant source region. At Site 643, Sequence 5 consists of compacted laminated mudstones with some chalk and siliceous mudstone grading into the zeolitic mudstones of Sequence 6 at the base. The configuration of this sub-basin lasted probably into the earliest Miocene. A change in relative subsidence during the deposition of Sequence 5 is reflected by a change from westward progradational downlap to eastward transgressive onlap east of sp. 8900 , profile $\mathrm{NH}-1$ (Fig. 16).

North of the Vøring Fracture Zone the sediment thickness decreases over the summit of the marginal high (profiles C-165 and C-167; Figs. 16, 22), suggesting that subsidence and sedimentation was delayed with respect to the southern plateau.

\section{Correlation Across the Vøring Plateau Escarpment}

We had encountered few problems in correlating the generally continuous, Neogene reflectors from the Vøring Basin to the outer Vøring Plateau. However, most of the deeper reflectors are interrupted by the escarpment or the structural high on its seaward side (Figs. 5, 16). The middle Oligocene reflector is, however, continuous over the southernmost part of the escarpment (Fig. 16). Thus, with the exception of reflector ME, we have been able to tie all sedimentary reflectors mapped west of the Vøring Plateau Escarpment to those in the Vøring Basin.

East of the structural high just seaward of the escarpment there is a small sequence, or wedge, of pre-lower Miocene deposits. Drilling at Site 338 (Figs. 16, 20) have confirmed that this sequence, at least locally, contains Oligocene and older sediments.

\section{EARLY TERTIARY VOLCANICS}

The large amounts of volcanic rocks recovered at Site 642 attest to the volcanic nature of the Vøring Plateau marginal high. The top of the flows were earlier correlated across the escarpment extending $30-40 \mathrm{~km}$ into the Vøring Basin (Talwani et al., 1983; Hinz et al, 1984). This horizon, denoted the inner flows, is also found landward of the Faeroe-Shetland Escarpment at the Møre Margin (Fig. 1). Actually, a series of volcanic features have been recognized in the outer Møre Basin (Smythe, 1983; Gatliff et al., 1984; Price and Rattey, 1984; Gravdal, 1985), whereas similar features in the western Vøring Basin have previously attracted little attention. Now, we first summarize the structure of the Vøring marginal high, then discuss the inner flows as one element of a complex volcanic sequence in the western Vøring Basin.

A zonation based on the signature of the acoustic basement surface and sub-basement features, originally suggested by Hinz et al. (1982) and Talwani et al. (1983), is commonly used to characterize the margin. This concept, with the zonations of Skogseid and Eldholm (1987), is applied in Figures 8 and 16.

\section{Voring Plateau Marginal High}

The elevated basement surface at the marginal high includes some oceanic crust (Zone IV) and two zones of different subbasement structuring beneath reflector EE (Zones II and III, Figs 8 and 16). We stress, however, the diachronous nature of $\mathrm{EE}$, which is documented by flow fronts offlapping in a seaward direction. At the southern plateau there are also excellent examples of younger lavas overflowing older sediment covered extrusives (Skogseid and Eldholm, 1987).

Zone III is underlain by the seaward-dipping reflector sequences, whereas Zone II forms a 10 - to $40-\mathrm{km}$ wide area west of the escarpment in which reflectors of poor continuity are sub-parallel to EE or dip gently landward. The transition between the zones is placed at the apex of the seaward-dipping wedge. Between the Lofoten and Vøring fracture zones a more poorly developed outer wedge (IIIB) is mapped west of the main inner wedge (IIIA) (Figs. 8 and 16). A band of high-amplitude, low-frequency reflectors of which the upper is denoted $\mathrm{K}$ (Hinz et al., 1982), marks the base of the sub-basement reflectors at the innermost high. The seismic record is indistinct with poor continuity below K. Skogseid and Eldholm (1987) noticed that $\mathrm{K}$ could only be traced $10-30 \mathrm{~km}$ beneath the most landward wedge, losing its character a short distance east of the onset of magnetic anomaly $24 \mathrm{~B}$. The seaward-dipping wedges exhibit a series of beds often becoming steeper with depth. Individual beds onlap K locally or pinch out within the wedge. Nevertheless, the detailed chronostratigraphy of the wedge is not fully 


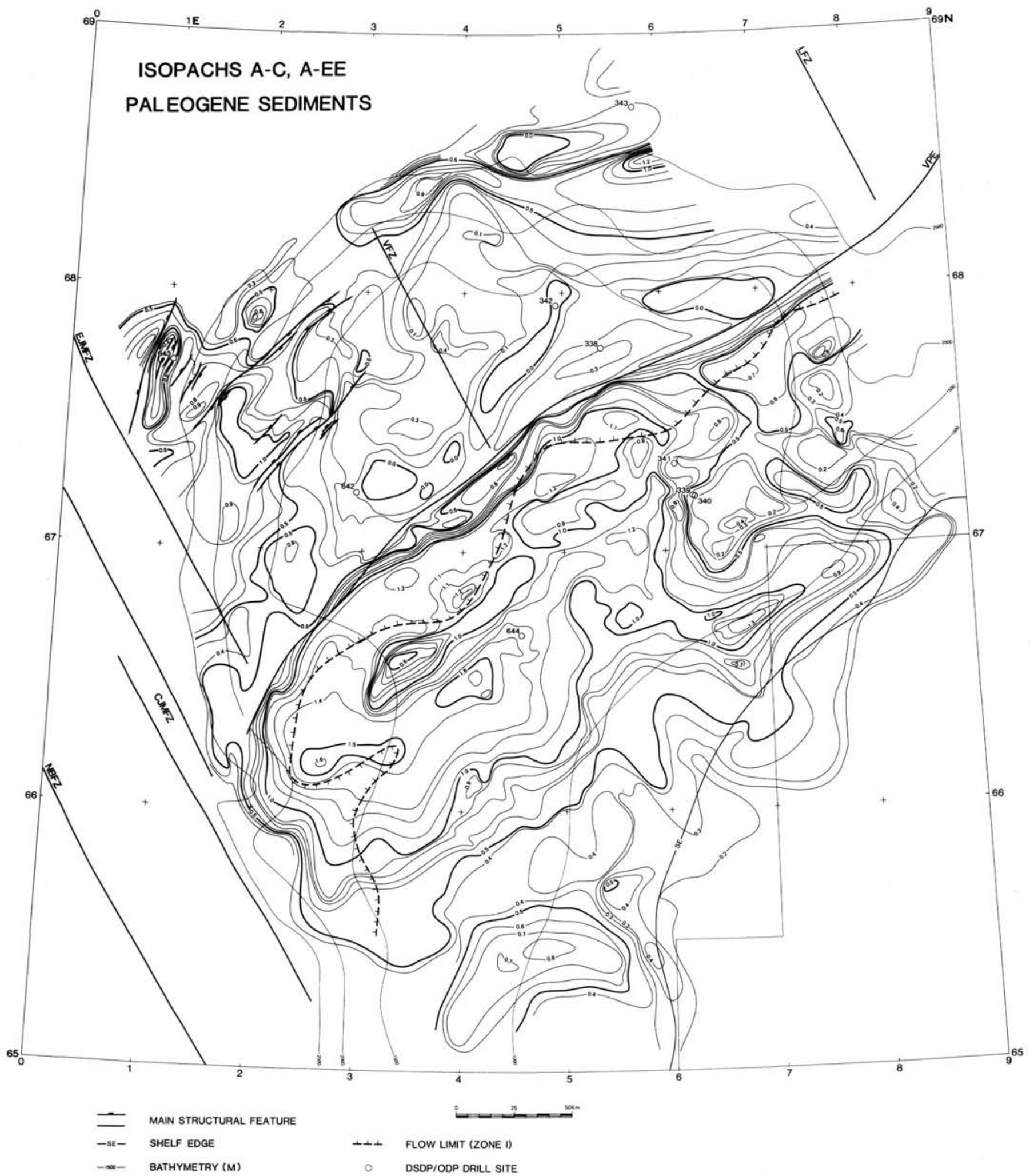

Figure 22. Isopach map of lower Miocene and Paleogene sediments. Includes the section between reflectors A (lower Miocene) and C (base Tertiary) in the Vøring Basin, and between A and EE (lower Eocene flow basalts) west of the Vøring Plateau Escarpment. Contour interval 0.1 s. Abbreviations as in Figure 2. 
understood, but truncations and unconformities suggest an episodic construction and varying relative subsidence.

The Leg 104 drilling answered many questions related to the crustal nature and structure of the marginal high. The results of Site 643 (Fig. 19) are compatible with lower Eocene oceanic crust near the total depth. More importantly, Site 642 drilled through the entire dipping sequence, recovering two distinctly different series of predominantly flow basalts and interbedded volcaniclastic sediments emplaced in a terrestrial environment (Fig. 17). The upper and lower volcanic series have been related to initial sea-floor spreading and late rifting-type volcanism respectively (Eldholm, Thiede, Taylor, et al., 1987; Eldholm et al., this volume).

At Site 642, the upper part of the sub-EE seismic sequence exhibits seaward-dipping reflectors of poor to moderate continuity (Fig. 17). Acoustically, this unit is the continuation of the better-developed part of the wedge sequence farther west. The onset of the low-frequency band of reflectors at the base of the wedge has been correlated with the tuffaceous unit at $1093 \mathrm{mbsf}$ that marks the change between the two volcanic series. Thus, reflector $\mathrm{K}$ is associated with the top of the lower volcanic series. Eldholm, Thiede, Taylor, et al. (1987) estimated a reflection coefficient of about -0.30 at this level, a magnitude that is expected to produce a prominent reflector in the seismic record. This interpretation yields an interval velocity of about $4.4 \mathrm{~km} / \mathrm{s}$ for the dipping sequence. It corresponds with ESP and sonobuoy solutions (Mutter et al., 1984), but is slightly higher than preliminary estimates from the VSP experiment. Rb-Sr dating suggests ages of 57.8 and $54.5 \mathrm{Ma}$ for the upper and lower series, respectively (LeHuray and Johnson, this volume), and dinoflagellates in the lower series sediments correspond to nannoplankton zones NP9 and NP10 at the Paleocene/Eocene boundary (Manum et al., this volume).

\section{Vøring Basin}

In the seismic record we have identified several regional features that are of probable igneous origin (Fig. 10). These are: sills, or low-angle dikes, within the Cretaceous sediments; a sillflow complex (Zone I or inner flows); a large number of small craters at the level of reflector TP; and the lower Eocene tuffs, reflector TP (Fig. 8). The mapping is based on seismic signature, stratigraphic setting, and comparison with volcanics west of the Vøring Plateau Escarpment. We have also been guided by similar seismic features in the same stratigraphic and structural setting along the margin northwest of Great Britain, where drillholes have confirmed their volcanic nature (Gibb et al., 1986; Hitchen and Ritchie, 1987; Jenyon, 1987; Mudge and Rashid, 1987).

The sills appear as sharp seismic signals of excellent continuity, in general terminating abruptly within the transparent and weakly layered Cretaceous sediments (Fig. 10). Locally, the reflectors are oblique with respect to a poorly developed stratification. Some intrusives disturb the base Cretaceous reflector, while none are observed in the sediments below reflector D or above the lower Eocene tuff. The intrusives both cut and follow the lower Tertiary listric fault planes, implying emplacement after the faulting. Moreover, the sills in the western Smøla and Fleina Rifts gradually migrate up in the section, approaching the boundary of the inner flows.

The top of the sill-flow complex, or the inner flows, constitutes the most prominent reflector in the Vøring Basin, effectively masking all underlying features. Profile B-9-81 (Fig. 5) shows that there is no seismic penetration below the flows, whereas $2-4 \mathrm{~s}$ of section is recognized where the profile crosses bights in the flow edge. The flows have a clear, lobate eastern limitation (Fig. 8) reflecting the topography of the base Tertiary horizon, which the flows onlap (Fig. 7). Moreover, the relief of the flow surface reveals individual fronts withdrawing towards the west. The interrelationship of the flows and sills make us prefer the term sill-flow complex to characterize Zone I. We believe the flows represent the endmember of a volcanic succession gradually changing from intrusive to extrusive character. This configuration, with flows overlying sills, might explain the striking seismic difference between the opaque inner flow sequences and the more transparent signature of the single, locally composite, sills farther east in the Vøring Basin.

The onlap of the flows onto base-Tertiary unconformity and the fact that they are located just below the lower Eocene reflector in the southwestern Vøring Basin, lead us to suggest that the sill-flow complex probably was emplaced at the transition between the Paleocene and Eocene epochs and/or in the earliest Eocene. This reasoning is, of course, only valid if the flows indeed are of extrusive nature in the southwestern basin. We favor an extrusive emplacement mainly because the flows, which fill in the base-Tertiary relief, are seismically similar and contiguous with those farther north. This suggests a genetically similar volcanic complex east of the entire Vøring Plateau Escarpment. It is natural to speculate that the emplacement of the volcanic complex is related to the two volcanic series drilled by ODP Leg 104 (Eldholm, Thiede, Taylor, et al., 1987). The composition of the youngest tuffs (Knox and Morton, 1988) indicates that they might be contemporaneous with the upper volcanic series in Site 642 , hence deposited after the onset of subaerial sea-floor spreading. In view of the time-transgressive nature of the flows on either side of the escarpment, we suggest that the inner flows, at the top of the flow-sill complex, are slightly older than those at the top of the marginal high. Thus, the inner flows were laid down during the time period between the emplacement of the lower volanic series and the uppermost upper series. A maximum time of about $3 \mathrm{Ma}$ is estimated for the emplacement of both volcanic series at the marginal high, although the entire upper series may in fact have been extruded over a much shorter time period (Eldholm et al., this volume).

The formation of the small eruptive vents or craters at the level of the lower Eocene horizon is not fully understood, but they were probably conserved due to a marine environment. Many of the features are similar to disturbances associated with volcanic sills and low-angle dikes off the U.S. East Coast (Jansa and PePiper, 1988). The craters probably reflect extrusive fissure vents, but a relationship with local sedimentary gas accumulations cannot be ruled out.

The different volcanic features in the Vøring Basin have a distinct but separate geographical distribution (Figs. 8, 23). Whereas the tuffs have been observed in large areas of the northeast Atlantic region (Knox and Morton, 1988), the sills and craters are restricted to the Tertiary marginal basin. Finally, the sill-flow complex is only observed in a 10 - to $40-\mathrm{km}$ wide zone just landward of the Vøring Plateau Escarpment. We believe, however, that the flow-sill complex is similar to the volcanic succession east of the Faeroe-Shetland Escarpment (Smythe et al., 1983; Gibb et al., 1986; Gibb and Kanaris-Sotiriou, 1988).

\section{DISCUSSION}

The seismic mapping revealed a series of sedimentary, volcanic, and structural units that is important for understanding Cenozoic margin evolution. The spacial relationship between the main regional structural and volcanic features are shown in Figure 23. Seaward of the Vøring Plateau Escarpment, we note the distribution of the various sub-basement reflectors (Zones II and III) and the structural high (Zone II) just west of the es- 


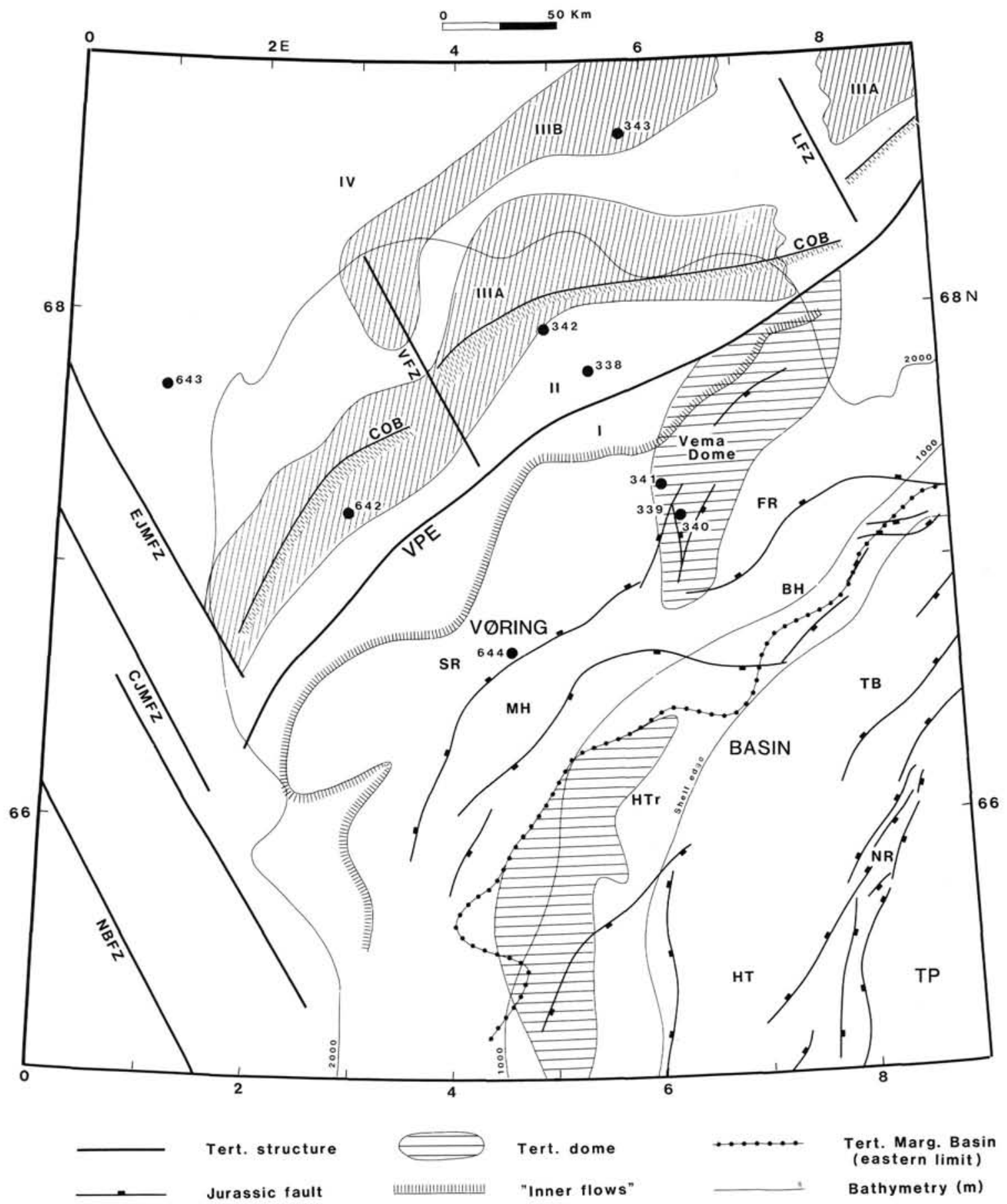

Figure 23. Main regional Mesozoic and Cenozoic features of the Vøring Plateau rifted volcanic continental margin. Volcanic zonation I-IV from Skogseid and Eldholm (1987). COB: continent-ocean boundary, TP: Trøndelag platform, VPE: Vøring Plateau Escarpment. Other abbreviations as in Figure 2.

carpment (Fig. 16). The Vøring Basin is divided into two provinces by the Molde-Bodø high. The western province comprises the Smøla and Fleina Rifts, whereas the eastern rift province includes the Traen Basin, Halten Trough, and Halten Terrace.

The Vøring Plateau margin has often been considered a nonextensional type of continental margin (Hinz et al., 1987; Mutter et al., 1988). We now document early Tertiary extension restricted to a 100 - to $150-\mathrm{km}$ wide region in the western Vøring Basin, the Tertiary marginal basin (Fig. 23). The early Tertiary igneous activity is also restricted to this basin and the Vøring Plateau marginal high.

\section{Pre-Cenozoic Basin Evolution}

Although we recognize a considerable pre-Cretaceous sedimentary section in many of the seismic profiles, we concur with Bukovics and Ziegler (1985) and Hagevang and Rønnevik (1986) that there is insufficient seismic resolution and penetration to make a contribution towards the pre-Cretaceous configuration of the Vøring Basin. In fact, most investigators have relied on data from Greenland and commercial wells at the Norwegian shelf to infer the early history of the deep Møre and Vøring basins (Larsen, 1987; Brekke and Riis, 1987). 
The Vøring Basin is primarily a Cretaceous basin developed by regional subsidence. The Late Jurassic-Early Cretaceous extensional episode that structured the entire Norwegian margin might actually be slightly time- transgressive northward (Gudlaugsson et al., unpublished data). Brekke and Riis (1987) proposed that the main structural pattern to a large extent reflects older, long-lived structural elements. The geometry of the Halten Terrace and the syncline within the Bodø high (Fig. 4), as well as observations from exploration on the shelf (Gabrielsen and Robinson, 1984; Gowers and Lunde, 1984; Price and Rattey, 1984) may be interpreted in terms of small magnitude strike-slip motions accompanying and/or postdating the extension.

The separation of the basin into two provinces by the MoldeBodø high (Fig. 23) has governed the Cretaceous sedimentation and subsidence of the Vøring Basin. During the Early Cretaceous, erosion took place both at the Trøndelag Platform and the intra-basinal highs. Most of the sediments were redeposited in the eastern province, whereas the Smøla and Fleina Rifts appear to have received less Lower Cretaceous sediments. The basin subsidence continued into the mid- and Late Cretaceous, and sediments covered the existing relief, establishing the regionally subsiding Vøring Basin. Under these conditions one would expect a dominance of Lower Cretaceous coarse clastic sediments flanking the highs and marine facies in the deeper basins, changing into basin-wide marine sedimentation in the Late Cretaceous (Larsen, 1987).

\section{Early Cenozoic Rift-drift Events and Intra-basinal Deformation}

The two different lava series recovered at Site 642 were emplaced subaerially or in shallow waters (Eldholm, Thiede, Taylor, et al., 1987). Thus, the Vøring Plateau did not experience a phase of rapid initial subsidence during the time of late rifting or early sea-floor spreading. However, simple thermomechanical models for crustal breakup assuming uniform extension reveal that the direction and magnitude of the initial subsidence is dependent on the crust-lithosphere configuration prior to rifting (McKenzie, 1978; Le Pichon and Sibuet, 1981). As the prerift crust becomes thinner, one would expect diminishing basement-involved faulting and subsidence associated with the new initial rift phase. In fact, uplift might take place under certain conditions.

At the Vøring margin two major rift episodes, the Late Jurassic-Early Cretaceous and the early Tertiary, are evident in the seismic record. In addition, the Late Jurassic crust between Norway and Greenland was probably thinned by previous rifting (Bukovics and Ziegler, 1985; Brekke and Riis, 1987; Larsen, 1987). The concept of rifting within much thinned continental crust was applied by Skogseid and Eldholm $(1987,1988)$ to the Vøring margin. Using available estimates of the Late JurassicEarly Cretaceous extension (Bøen et al., 1984; Bukovics et al., 1984 , Gravdal 1985), they showed that initial uplift or nonsubsidence could have taken place in the early Tertiary, causing the formation of a volcanic margin.

The present seismic interpretation has allowed new extension estimates of the Late Jurassic-Early Cretaceous and the early Tertiary rift episodes. Calculations by Pedersen and Skogseid (this volume) indicate differential extension across the Vøring Basin and that previous stretching factors for the Late JurassicEarly Cretaceous rifting probably are too high. They suggested the maximum pre-Cenozoic extension took place in the eastern Vøring Basin and computed a stretching factor of 1.9 for the southern Traen Basin, decreasing to 1.3 and 1.5 at the Molde high and Smøla Rift respectively (Fig. 5).

The small amount of pre-Cenozoic extension in the western Vøring Basin would probably not have produced initial uplift in the early Tertiary assuming a uniform extension model. On the other hand, models introducing differential extension (Skogseid and Eldholm, 1988) or partial melting (White et al., 1987; Mutter et al., 1988; Pedersen and Skogseid, this volume) could account for the anomalous level of crustal generation. In particular, the existence of large volcanic edifices at the Vøring margin and other margins in the North Atlantic makes partial melting attractive. Although initial uplift at the Vøring Plateau is consistent with data and geodynamical models, its magnitude is poorly constrained because the volcanics hide much of the underlying structural and stratigraphic record.

The stratigraphy of the outer Vøring Basin reveals that the base-Tertiary reflector can be considered a rift-unconformity, associated with uplift and erosion during the early Tertiary. The reflector is an erosional unconformity in the entire basin west of the Molde-Bodø high, and the Paleocene and lower Eocene sediments are absent in a 10 - to $50-\mathrm{km}$ wide region east of the Vøring Plateau Escarpment (Figs. 24, 25). The unconformity truncates and smooths the relief of the near base-Tertiary listric fault blocks, disappearing under the inner flows. Subsequent to uplift, the basin started subsiding with sediments onlapping the base-Tertiary horizon during a westward transgression of the shoreline. The early Eocene situation is shown in Figure 8. We infer that most of the Paleocene sediments in the western Vøring Basin (Fig. 24) were derived from the elevated region in the west.

During the Early Eocene there was an additional pulse of uplift at parts of the Smøla and Fleina rifts (Figs. 5, 25). It is particularly evident within the southern Smøla Rift where the baseTertiary unconformity (Fig. 7) overlies a northeast-trending ridge, the Lovund Ridge of Bukovics et al. (1984). The well-defined sediment minimum in Fig. 22 documents that the ridge has been a positive structure during Paleogene times. From stratigraphic considerations we estimate that as much as $800 \mathrm{~m}$ of Upper Cretaceous sediments may have been eroded locally at the inverted Smøla Rift.

The listric fault deformation of the Cretaceous sediments in the Smøla and Fleina rifts conflicts with the idea of a nonextensional Vøring margin. While these faults are prominently developed, they only exist within the older Late Jurassic-Early Cretaceous rifts (Figs. 5, 7), implying that the early Tertiary extension only developed prominent faults in the thickest Cretaceous sediments. On the other hand, the underlying Late Jurassic-Early Cretaceous faults show no significant reactivation.

Our interpretation of the listric fault system implies that the observed extension is mainly taken up by ductile deformation of the sedimentary rocks, possibly by over-pressured shales in the Lower Cretaceous section. The main question is, however, how to create extension without involving an observable deformation of the pre-Cretaceous sediments. If the listric faults only existed above the local domes, they might simply reflect collapse structures related to the doming (Shelton, 1984), but the seismic data show a wider region of deformation (Fig. 5). Furthermore, regional crustal extension must have taken place to account for the postrift marginal subsidence. Pedersen and Skogseid (this volume) have shown that the early Tertiary rift episode yields differential crustal extension across the Tertiary marginal basin, and a stretching factor of 1.6-1.9 is calculated in the Smøla Rift. "We therefore relate the extension to lithospheric thinning and development of a thermal anomaly at the base of the crust. Brun and Choukroune (1983) have shown that an increased thermal gradient could cause a brittle-ductile crustal transition to take up lateral displacement. We do not believe that the main level of crustal detachment lies within the sediments, but the model explains how a thin segment of the upper crust may be left relatively stable between an upper ductile shale and a deeper main zone of detachment caused by the thermal anomaly (Smith and Bruhn, 1984). On the Norwegian shelf Gabrielsen (1986; in 


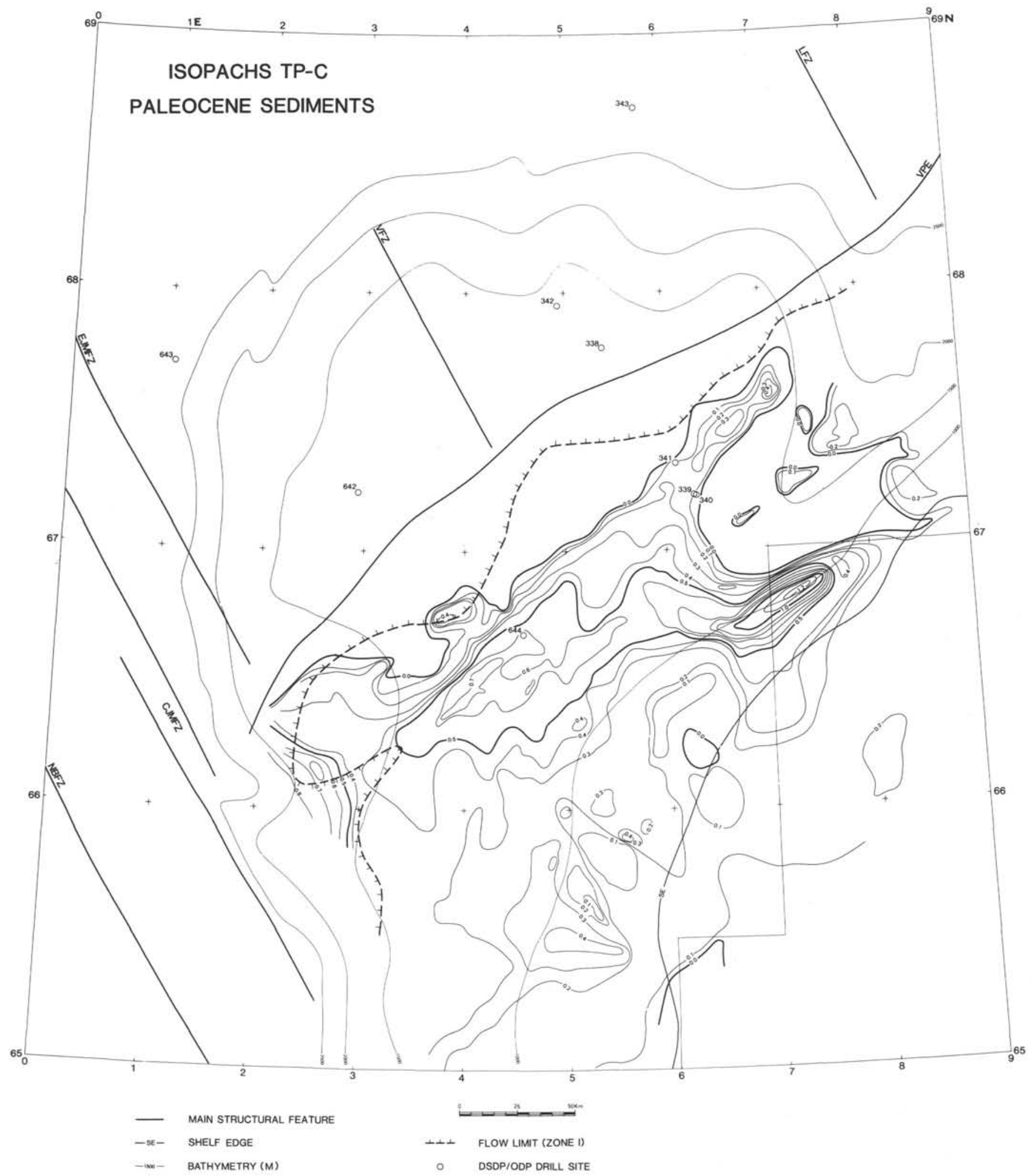

Figure 24. Isopach map of Paleocene sediments. Includes the section between reflectors TP (lower Eocene) and C (base Tertiary). Contour interval 0.1 s. Abbreviations as in Figure 2. 
So. 1 10vel
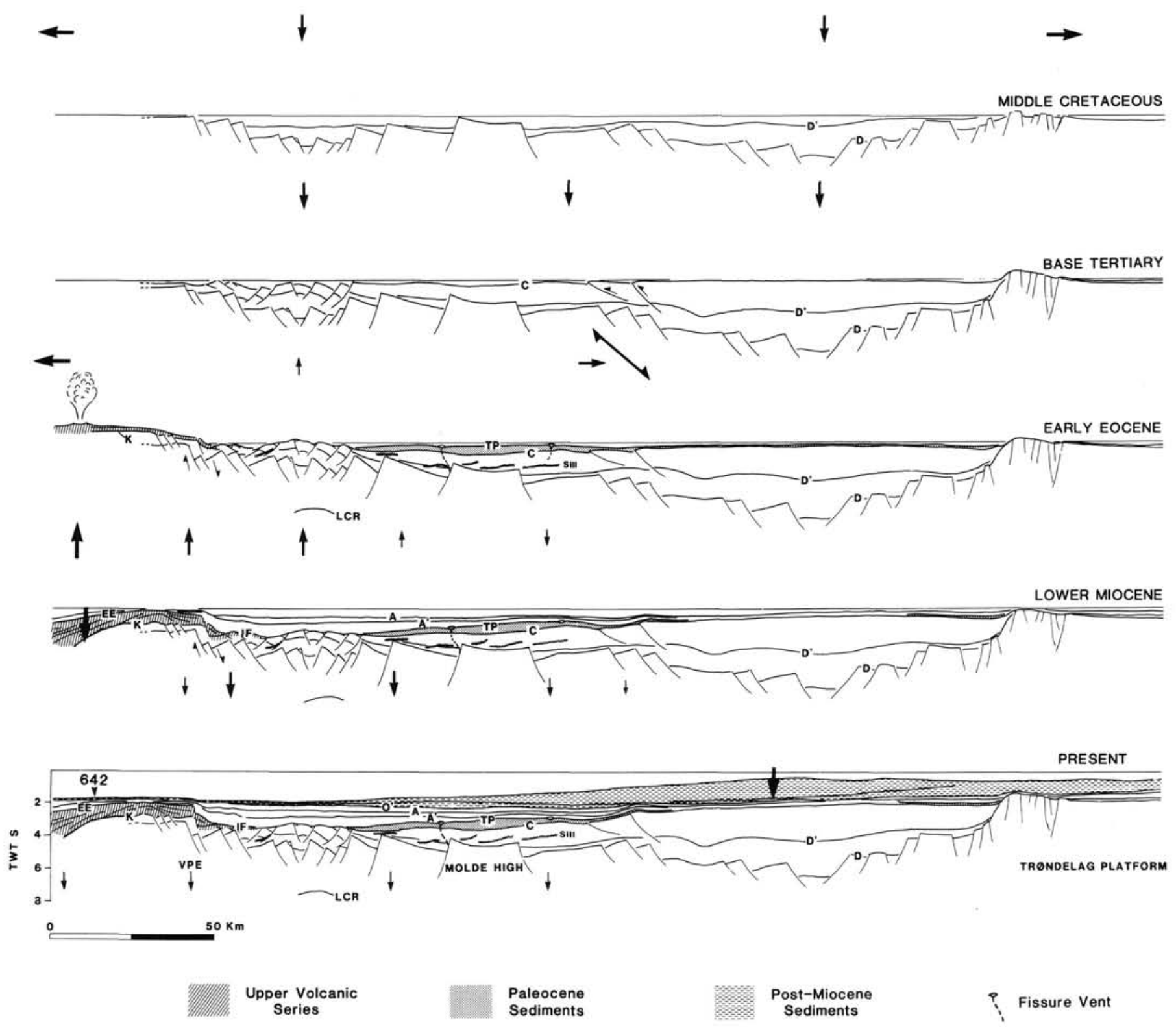

Figure 25. Evolutionary time slices showing the Cretaceous and Cenozoic development of the Vøring Basin. Arrows show relative horizontal, vertical and shear movements. For reflector nomenclature, see text.

press) has demonstrated that older zones of weakness are often reactivated, causing deformation within the sediments without observed offset of the older structures. The sedimentary deformation normally develops listric faults, whereas the deeper and older faults tend to have planar, steep surfaces.

The igneous activity postdates the listric faulting in the Cretaceous sediments. In general, the volcanic intrusives in the Tertiary marginal basin show a geometrical relationship with the Late Jurassic-Early Cretaceous fault fabric (Fig. 8). Probably, the old zones of weakness have guided the upward flow of the melts.

Returning to the mechanism responsible for the initial uplift, most of the observations can be explained by a uniform extension model with partial melting. Using parameters from Skog- seid and Eldholm (1987) and this study, Pedersen and Skogseid (this volume) predicted extension in a 150 - to $200-\mathrm{km}$ wide area landward of the continent/ocean boundary. Their model implies early Tertiary uplift of the entire basin west of the MoldeBod $\varnothing$ high, and the continent/ocean boundary could have been elevated as much as $900 \mathrm{~m}$ above sea level. Moreover, melt was produced in decreasing amounts away from the incipient plate boundary, relative to the rate of extension.

There is an apparent correlation between the lower crustal reflector (LCR, Fig. 5) and the parts of the Mesozoic Smøla and Fleina Rifts that experienced maximum uplift in the earliest Tertiary. Possibly, the thin pre-Cenozoic crust below the rifts acted as a trap for low-viscosity melts underplating the crust during rifting, causing the local changes in relative uplift. If so, reflec- 
tor LCR is a remnant of the pre-Cenozoic base of the crust. Nevertheless, most of the melt was concentrated in the region of continental breakup. During breakup, the volcanic extrusion rate became much larger than during the previous rifting stage. This subaerial volcanic surge created the dipping-reflector sequences as well as the tuffs in the Vøring Basin. The onlap of the tuffs onto the base-Tertiary unconformity east of the Vøring Plateau Escarpment shows that the marginal high and western Vøring Basin stayed above the erosional base until after the tuffs had been deposited.

The Vema Dome and its continuation south of the MoldeBodø high (Fig. 23) are the main areas of Cenozoic intra-basinal deformation in the Vøring Basin. These features have been described as caused by igneous intrusives in the Cretaceous sediments, mobilization of pre-Kimmeridgian evaporites or deep crustal movements (Hinz et al., 1984). On the other hand, Mutter (1984) suggested deformation throughout the Cretaceous reaching its final stage in the Oligocene. He proposes a diapiric origin for the movements, whereas Rønnevik et al. (1979) related the domes to shear zones in conjunction with plate tectonic events in the Norwegian-Greenland Sea. Most investigators concur, however, that the main doming took place during Oligocene to early Miocene times (Bøen et al., 1984; Bukovics et al., 1984; Hinz et al., 1984). On the adjacent continental shelf there is evidence of Oligocene wrench movements resulting in folding, reverse faulting, and reverse rejuvenation of normal faults in a north-northwest direction (Gabrielsen and Robinson, 1984; Gowers and Lunde, 1984; Larsen and Skarpnes, 1984).

The composite nature of the domes lead us to propose a twostage evolutionary model. A latest-Cretaceous to early Tertiary strike-slip regime responsible for the reverse faulting was followed by gentle flexural updoming ending during the early Miocene. Locally, the domes created a surface relief that has guided sedimentation until present time. We believe the deformation of the Cretaceous sediments was initiated by dextral strike-slip transpression associated with the early Tertiary rifting episode, probably including minor reactivation of some of the older Mesozoic lineaments (Fig. 23). The deformed sediments, probably marine shales, were subsequently mobilized by the strike-slip movements. During the Paleogene the doming kept pace with sedimentation, but ceased during the early Miocene. Nevertheless, diapirsm has continued locally over the Vema Dome, where a large number of mud diapirs, drilled during DSDP Leg 38 (Talwani, Udintsev, et al., 1976), pierce the sea floor (Fig. 9).

The Vema Dome is best developed in the southern part of the Fleina Rift where the doming is superimposed on the early Tertiary local inversion of the rift (Fig. 5). Profile C-165, which crosses the rift, probably reflects four tectonic events (Fig. 9). First, the Late Jurassic-Early Cretaceous graben was formed. Then, there was Late Cretaceous to early Tertiary extension expressed by listric faults, whereas the steeper reverse faults imply that the extension was accompanied by transpression. Finally, large-scale doming was initiated continuing through Paleogene times. The transcurrent stress regime may also be responsible for the distinct syncline along the Bodø high. Although the dome over the Halten Trough is less spectacular than the Vema Dome, it has a clear subsurface expression. We do point out, however, that much of its prominence may be ascribed to differential subsidence during the Tertiary (Fig. 25).

The scenario above can be summarized in the following evolutionary steps, noting that the ages are considered relative only (Fig. 25):

155-140 Ma. Structuring of the incipient Voring Basin by the Late Jurassic-Early Cretaceous tectonic episode.

140-100 Ma. Early Cretaceous differential subsidence and sedimentation. Local highs remained emerged. Main depocen- ter east of Molde-Bodø high. Enhancement of the horst-graben relief.

100-65 Ma. Regional basin subsidence and high sediment influx smoothing the basin relief.

65-58 Ma. Extension causing asthenospheric doming, listric faulting, partial melting, and melt migration towards the base of the crust. Initiation of intrusive activity. Regional uplift of the outer Vøring Basin and local inversion within the Late Jurassic-Early Cretaceous Smøla and Fleina Rifts. A strike-slip stress regime causes reverse faulting and initiation of large intra-basinal doming.

58-57 Ma. Continued thinning of the lower crust and emplacement of intrusives within the Vøring Basin sediments. The volcanism is most intense west of the Vøring Plateau Escarpment where dikes cut through a much thinned crust to the surface, constructing the lower volcanic Series. Sills, dikes, and some extrusives build up the core of the flow-sill complex of Zone I in the adjacent Vøring Basin.

$57 \mathrm{Ma}$. Continental breakup releasing large amounts of magma, initiating Icelandic-type sea-floor spreading.

57-54 Ma. Icelandic-type spreading produce a volcanic complex of flows and interbedded sediments comprising the seaward-dipping reflector sequences in Zone III as well as flows above reflector $\mathrm{K}$ in Zone II, and some flows in Zone I. Ashes and tuffs deposited over a wide region. Intrusive activity ceases in the Vøring Basin.

Post-54 Ma. The volcanic surge decreases and the spreading axis subsides causing a change in mode of crustal generation from Icelandic to normal oceanic crust.

\section{Post-rift Sedimentation}

After the initial breakup the margin subsided primarily due to thermal cooling of the lithosphere. The subsidence and subsequent sedimentation is presently reflected in the relative distribution of the postrift sediments (Figs. 8, 11-13, 22, 24, 26).

The distribution of Paleogene and Paleocene sediments (Figs. $22,24)$ illustrates the westward migration of the main depocenter since the time of rifting. During the late rifting stage, erosional products from the emerged Vøring Basin west of the Molde-Bod $\varnothing$ high were transported to the east, building the thick (maximum 1.2 s) Paleocene-lower Eocene sequence in the vicinity of the Molde-Bodø high (Fig. 24). The Paleocene isopachs also show the local inversion of the Fleina Rift, leaving depocenters on either side of the structure (profile 165, Fig. 5). After breakup, the Tertiary marginal basin subsided most rapidly, with sediments transgressing westward reaching the Vøring Plateau Escarpment during the middle Eocene.

The relief of the Tertiary marginal basin became gradually smoother during the Paleogene and Miocene. The Vøring Basin east of the Tertiary marginal basin experienced a relatively small amount of subsidence and sedimentation during this period (Figs. 5, 22). In this area deposition took place at shallow water depths throughout the Tertiary, allowing erosion of all horizons from the lower Eocene to the base Pliocene (Figs. 8, 11-13).

We recognize a post-Miocene phase of increased subsidence and large-scale sedimentation reflected by a thick sequence over the Trøndelag Platform and the inner Vøring Basin (Fig. 26). The sequence contains a number of prograding units which have built out the shelf edge to its present position where the sediments have a maximum thickness of about $1.2 \mathrm{~s}$. The uppermost part of the sequence is, however, toplapped by flat-lying Quaternary beds becoming $0.2-0.4 \mathrm{~s}$ thick east of the shelf edge. West of the shelf edge the post-Miocene sediments thin rapidly, leaving only $0.1-0.3 \mathrm{~s}$ of conformable layers east of the Vøring Plateau Escarpment. The origin of this post-Miocene event, which is observed along the entire eastern NorwegianGreenland Sea continental margin (Eldholm et al., 1984), is poorly understood but might be a response to a late Cenozoic uplift of the Fennoscandian landmass. 


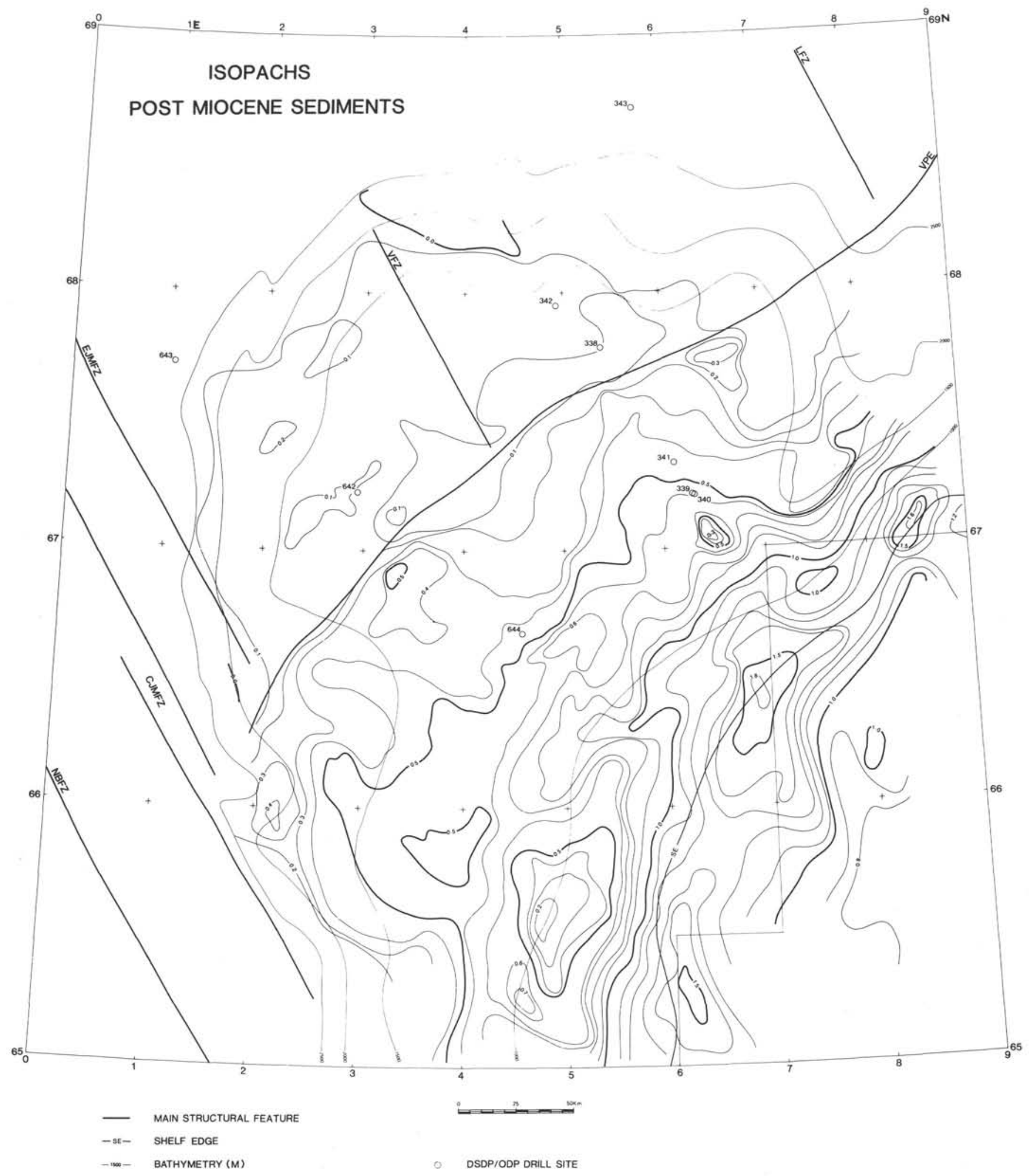

Figure 26. Isopach map of post-Miocene sediments. includes the section between reflector $\mathrm{O}^{\prime}$ (base Pliocene) and the sea floor in the Vøring Basin, and between UP (upper Pliocene) and the sea floor west of the Vøring Plateau Escarpment. Contour interval 0.1 s. Abbrevations as in Figure 2. 
At the Vøring marginal high, the subaerial sea-floor spreading had left behind a volcanic edifice including huge wedges of seaward-dipping reflectors towards the end of the early Eocene. The westward jump in the spreading axis just prior to anomaly 23 time (Fig. 2) is reflected by the old rift depression south of the Vøring Fracture Zone. In the early to middle Eocene the western part of the marginal high submerged and the basaltic basement became covered with a succession of Eocene and younger sediments. Terrigenous material, mainly derived from the still elevated eastern part of the marginal high, dominates the basal section, gradually changing into hemipelagic and pelagic compositions (Talwani, Udintsev, et al., 1976; Eldholm, Thiede, Taylor et al., 1987). The summit region of the high stayed elevated without receiving appreciable sediments before early Miocene time (Figs. 22, 27). Thus, the varying sediment load might have contributed to the differential subsidence across the outer margin.

The depositional evolution of the outer Vøring Plateau is summarized below, illustrated by a transect through the ODP drill sites south of the Vøring Fracture Zone (Fig. 27). The region north of the fracture zone has been discussed by Caston (1976).

1. Early Eocene. Erosion of the young lavas and redeposition of volcaniclastic sediments in the adjacent landward basin and in the rift depression at the western marginal high (Sequence 7).

2. Middle Eocene to middle Oligocene. The relief of the rift depression is maintained during regional subsidence, causing transgression and progressive deposition of zeolitic mudstones (Sequence 6) derived from source areas on either side of the rift.

3. Middle Oligocene to early Miocene. Except for the summit area the marginal high is covered by sediments (Fig. 12). During this period the outer plateau started subsiding more rapidly than the inner part, leaving the eastern summit region as the main source area. This resulted in deeper marine chalks and siliceous mudstones at the outer plateau, while the zeolitic mudstones, derived from the still exposed lavas and redeposition of older sediments, dominate farther east (Sequence 5). Erosion at the lower Miocene unconformity and a high thermal gradient, may account for the distinct diagenetic boundary observed at Site 643 .

4. Post-early Miocene. The continued regional subsidence caused a rapid transition from shallow to deep marine environments over the entire plateau. However, depositional patterns reflect periods of both local and regional erosion and redeposition. As these processes occurred during times of ample biogenic supply, we relate them to changes in current patterns at the young margin, possibly influenced by sea-level fluctuations. The disturbed, poorly consolidated middle to lower Miocene diatom muds and oozes of Sequence 4 were laid down during a period of rapid progradation. The deformation (Fig. 18) might be syn-depositional or related to the later overburden of the prograding, mainly biogenic sediments in Sequences 2 and 3, initiating differential loads causing local mass movements in the water-rich muds below. There is poor seismic resolution in the uppermost glacial-interglacial sequence, but we document strong current-induced erosion of these, as well as the underlying sediments at the flanks of the plateau.

A primary observation is the existence of exposed flow basalts at the summit of the Vøring marginal high during the early Miocene. However, sediments gradually onlap and also cover these lavas. The northern part of the high stayed without sediments for the longest time (Figs. 13, 16, 22), becoming completely covered during the late Pliocene. It is therefore likely that the summit was a source region for parts of the prograding Neogene sequences observed at the west and northwest flanks of the plateau.

\section{Voring Plateau Escarpment}

The escarpment is a spectacular linear feature along the entire Vøring Plateau. In our maps we have marked it at the maximum gradient change or eastern termination of reflector EE. Although the detailed expression of the escarpment varies lo- cally, Hagevang et al (1983) demonstrated that it is associated with a continuous, sharp negative magnetic anomaly at the plateau proper. The nature and origin of the escarpment has been much debated after Talwani and Eldholm $(1972,1973)$ described it as a first-order geological feature related to the continentocean boundary. From the preceeding discussion a relationship with the transitional crustal region is evident, although it may not represent the actual line of early Tertiary breakup.

By analogy with the Faeroe-Shetland Escarpment, Smythe et al. (1983) proposed the escarpment to be a flow edge separating terrestrially erupted basalts on top of Mesozoic sediments from a restricted shallow shelf, thus being a paleo-shoreline. In contrast, Talwani et al. (1983) and Mutter et al. (1984) maintained the relationship with the continent/ocean boundary. There is also little agreement about the relative movements along the escarpment. Caston (1976) proposed that it has acted as a normal fault throughout the Tertiary, and Theilen et al. (1987) indicate recent activity. Mutter (1984), on the other hand, precludes significant movement after the end of the early Eocene. Recently, Skogseid and Eldholm (1987) have suggested that the escarpment might represent a reactivated Late Jurassic-Early Cretaceous fault leaving a strongly contaminated continental block between the escarpment and the continent/ocean boundary located beneath the innermost wedge of the seaward-dipping reflectors.

We note that the Mesozoic faults at the western flanks of the Smøla-Fleina Rifts probably exist beneath the flow-sill complex adjacent to the escarpment. Using a schematic section across the Smøla Rift we suggest the following evolution (Fig. 28):

1. Paleocene. Listric faulting within the Smøla and Fleina Rifts. Regional uplift centered west of the rifts with contemporaneous erosion and redeposition of sediments farther east in the Vøring Basin.

2. Paleocene-Eocene. Extensive volcanic intrusions and some extrusive activity emplacing the lower volcanic series. Toward the end of the period there is reactivation of Mesozoic faults, bringing the western blocks above sea level.

3. Earliest Eocene. Continental breakup. Emplacement of upper volcanic series, terminating with reflector $\mathrm{EE}$ and the inner flows on either side of the escarpment. Fault movements continue, diminishing toward the end of the volcanic surge.

4. Eocene-Oligocene. Regional flexural subsidence is amplified by a differential component due to sediment loading on either side of the escarpment.

5. Post-Oligocene. Continued regional subsidence.

\section{SUMMARY AND CONCLUSIONS}

In conjunction with ODP Leg 104 drilling at the Vøring Plateau we have interpreted a large amount of regional seismic data from the Vøring Basin and the Vøring marginal high to study the evolution of the volcanic Vøring Plateau margin. By tying the seismic data to ODP and DSDP drilling results at the Vøring Plateau as well as to information from commercial drilling on the continental shelf, we have established a regional framework for the margin evolution. Although ambiguities still exist, the interpretation has provided much new information constraining the geological models for the Vøring Plateau margin. Furthermore, the relationship between structural, volcanic, and depositional events documented during the late rifting to early drifting stages might have bearings on volcanic passive margins in general.

The Cenozoic Vøring Plateau margin lies within a post-Caledonian basinal region between Norway and Greenland that experienced several tectonic episodes prior to Late Jurassic time. We have little information from the Vøring Basin during these times, but periods of extension may have left a thinned crust. During the Late Jurassic renewed extension took place, culminating in the Late Jurassic-Early Cretaceous tectonic episode 
EARLY EOCENE (A22)

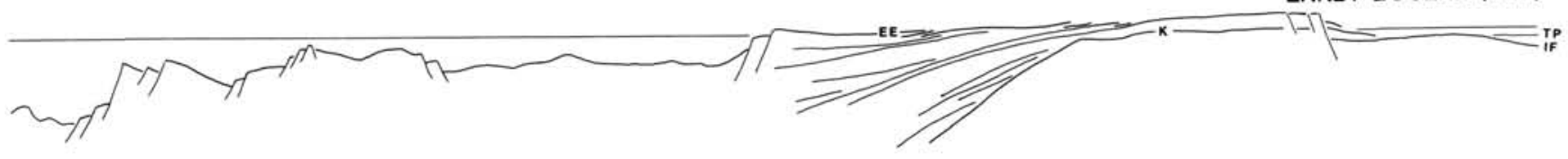

MIDDLE OLIGOCENE

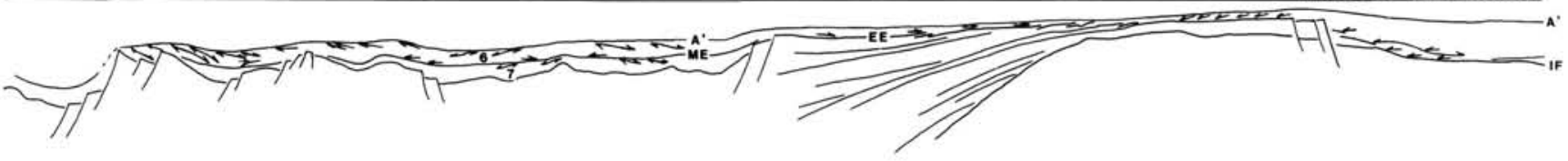

LOWER MIOCENE

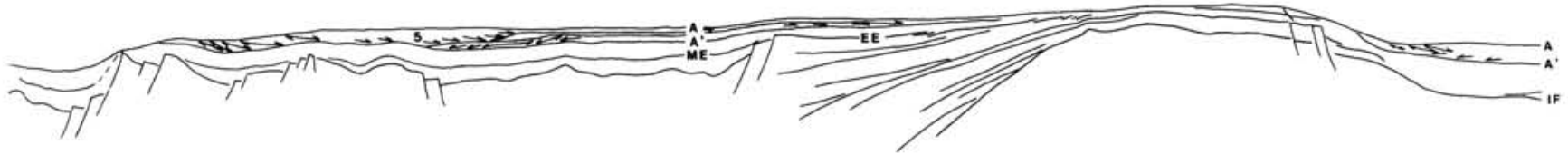

MIDDLE MIOCENE

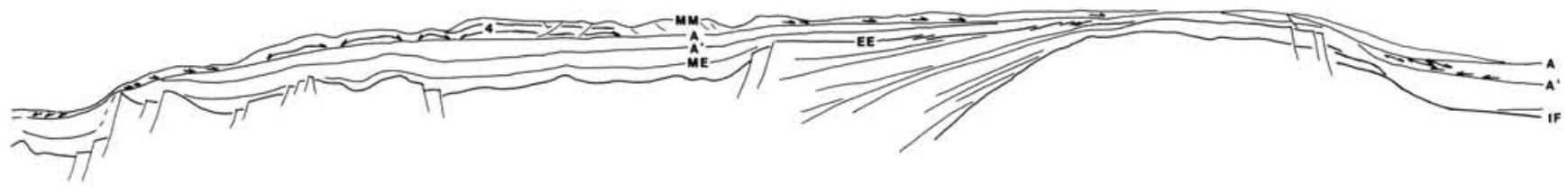

PRESENT

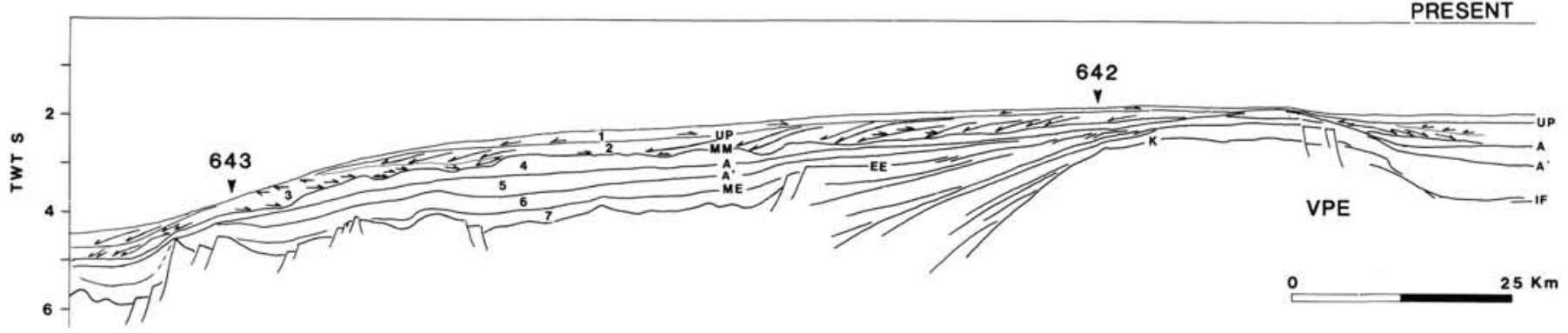

Figure 27. Evolutionary time slices showing the Cenozoic development of the outer Vøring Plateau. Numbers 1 to 7 refer to the depositional sequences discussed in the text. VPE: Vøring Plateau Escarpment.

that structured the entire continental margin off Norway. This event was predominantly extensional but strike-slip components are observed locally. The Vøring Basin developed during the Cretaceous when it experienced large-scale subsidence with respect to the Trøndelag Platform farther east. During that period the basin was divided into two provinces by the central MoldeBodø high (Fig. 23), which governed both the Cretaceous sedi- mentation and the extent of the later crustal extensional regime associated with the opening of the Norwegian-Greenland Sea.

At the end of the Cretaceous period the stable, gently subsiding basin again came under tension followed by upwelling of asthenospheric material. This resulted in regional uplift of the outer basin province from the beginning of the Tertiary to the early Eocene. The crustal extension is expressed by listric faults 


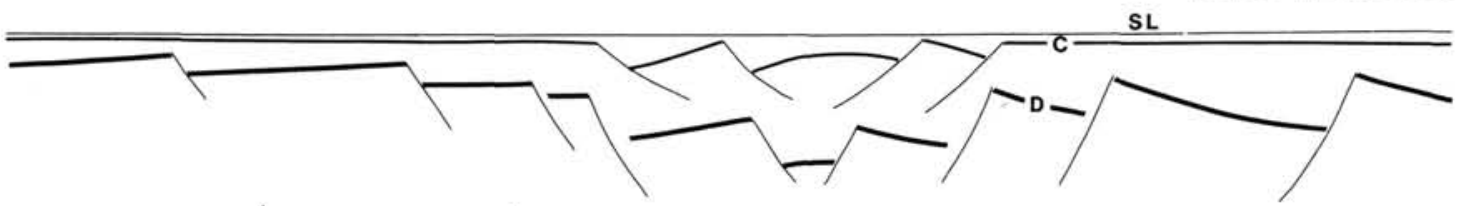
A

PALEOCENE-EOCENE
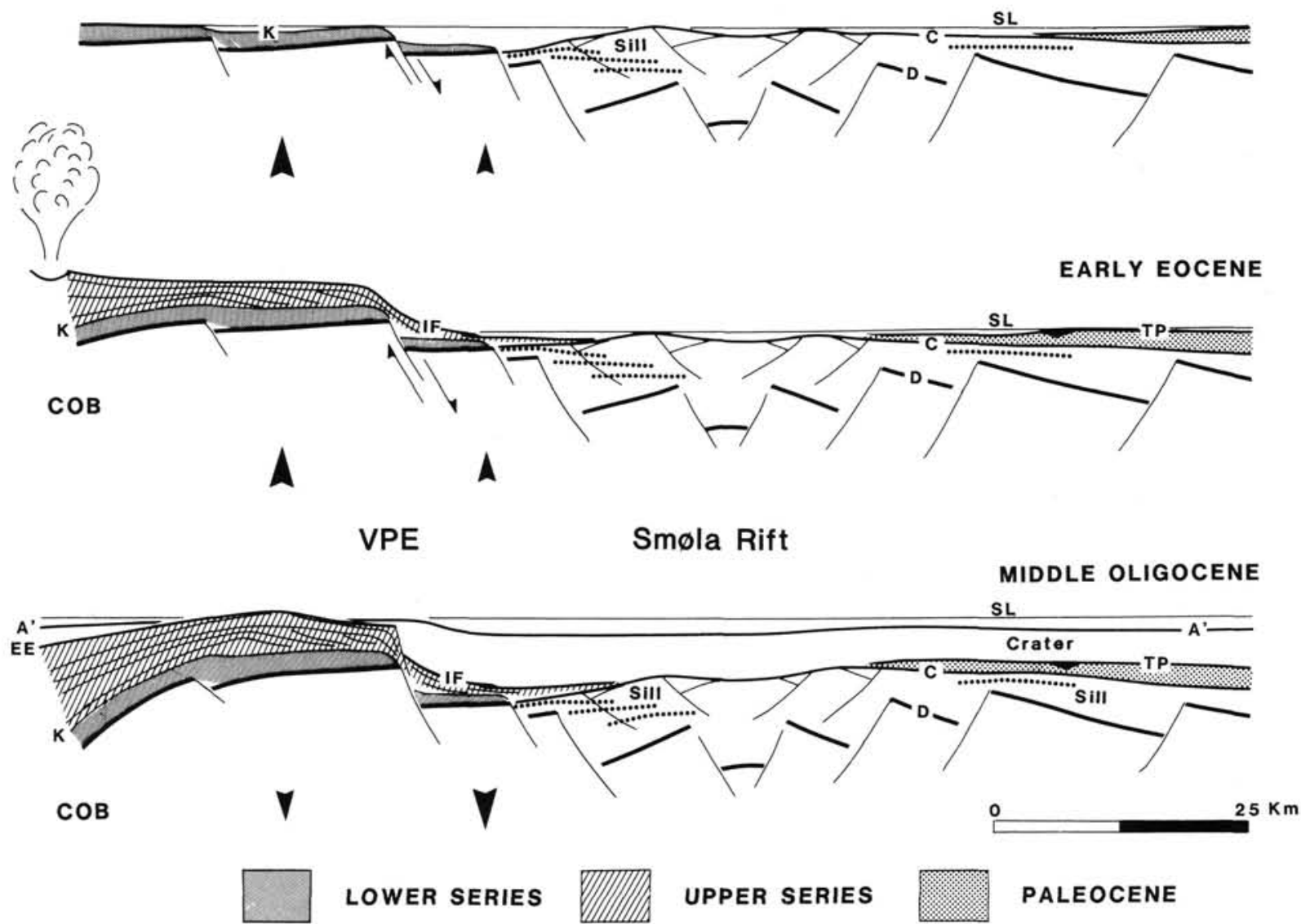

Figure 28. Schematic evolutionary time slices showing the development of the Vøring Plateau Escarpment (VPE). Arrows show relative vertical movements. COB: Continent/ocean boundary, SL: sea level, $\mathrm{A}^{\prime}$ : middle Oligocene, TP: lower Eocene, IF: inner flows, EE: lower Eocene flow basalts, K: boundary between upper and lower volcanic series, C: base Tertiary, D: base Cretaceous.

within the Cretaceous sediments, intrusive activity and local inversion of parts of the Late Jurassic-Early Cretaceous Smøla and Fleina Rifts. These observations appear to rule out the concept of the nonextensional volcanic rifted margin. The early Tertiary extension and volcanism were, however, restricted to the outermost $150-200 \mathrm{~km}$ of the Vøring Basin, the Tertiary marginal basin. Moreover, the Tertiary extension was differential across the outer margin, increasing toward the Vøring Plateau Escarpment.

The extensive igneous activity in the Tertiary marginal basin is manifested by intrusive low-angle dikes and sills, explosive craters or fissure vents, extrusive flows, and tuffs and ashes. Initially, the intrusives penetrated the stretched continental crust over a wide zone, gradually moving up-section approaching the 10 - to $40-\mathrm{km}$ wide flow-sill complex just landward of the Vøring
Plateau Escarpment. At time of crustal breakup, the main injection zone was at or above sea level. The abnormal elevation, coupled with a high rate of injection, caused the formation of the Vøring Plateau marginal high. The initial sea-floor spreading was of the Icelandic-type, constructing the wedges of seaward-dipping reflectors as documented by the upper volcanic series at Site 642 . We believe the intrusives in the Vøring Basin represent pre-opening basalts similar to the andesitic magma of the lower volcanic series at Site 642, although some of the sills/ dikes near the escarpment may contain mixed or upper series magma. The flow-sill complex is interpreted to comprise both lower and upper series volcanics, but the inner flows at the top are probably older than the youngest flows at the marginal high. The upper Paleocene-lower Eocene tuff horizons recognized in large regions of the North Atlantic show affinities to 
the lower-upper series succession at Site 642. Thus, the lower Eocene tuff marker in the Vøring Basin is associated with the upper volcanic series at the marginal high.

The post-opening sedimentation is primarily governed by the thermal subsidence of the Tertiary marginal basin and the submergence of the Vøring marginal high. At the high, the oldest sediments above the basalt are of terrigeneous origin, gradually changing to hemipelagic and pelagic compositions covered by a sequence of glacial deposits. Local disturbances in the sediments reflect local instability due to overpressure as well as intense erosion and redeposition. The main seismic unconformity, earlier associated with the middle Oligocene drop in sea level, is redated to the lower Miocene. The sediment distribution is compatible with an extinct early Eocene rift south of the Vøring Fracture Zone. A most important observation is that the summit of the southern marginal high was not sediment covered before the early Miocene and that the region north of the Vøring Fracture Zone became completely covered during the Pliocene.

The Vøring Plateau Escarpment is a volcanic front representing the landward termination of the massive volcanic edifice emplaced subsequent to the time of breakup. The rifting process may have reactivated some older Late Jurassic-Early Cretaceous lineaments, perhaps creating an uplifted block as suggested by Schuepbach and Vail (1980). This would enhance the relief of the escarpment. Its expression has further been amplified by Cenozoic differential sediment loading.

Within the Vøring Basin we have mapped a zone of northtrending domes originating from dextral transcurrent intraplate forces creating local reverse faulting at the time of the Cenozoic rifting. These movements mobilized shales resulting in contemporaneous doming and sediment deposition into the early Miocene. Local diapirism still continues at the Vema Dome. A late, post-Miocene, pulse of increased subsidence and sediment deposition is centered around the present shelf edge and is part of a regional event observed along the entire eastern NorwegianGreenland Sea margin.

\section{ACKNOWLEDGMENTS}

The seismic data used in this study have been made available by Bundesanstalt für Geowissenschaften und Rohstoffe; Department of Geology, University of Oslo; Institut Français du Pétrole; Norwegian Petroleum Directorate; Seismological Observatory, University of Bergen; and Statoil. We are grateful to Jan Inge Faleide, Steinar Thor Gudlaugsson, Vidar B. Larsen, Tom Pedersen and Sverre Planke for helpful advice and stimulating discussion. We are particularly grateful for critical reviews by Roy Gabrielsen and Annik M. Myhre. Assistance from Statoil in producing many of the maps and figures is much appreciated. The project has been supported by grants from the Norwegian Research Council for Science and the Humanities, and Statoil.

\section{REFERENCES}

Brekke, H., and Riis, F., 1987. Tectonics and basin evolution of the Norwegian Shelf between $62^{\circ} \mathrm{N}$ and $72^{\circ} \mathrm{N}$. Norsk Geol. Tidskr., 67: 295-322.

Brun, J-P, and Choukroune, P., 1983. Normal faulting, block tilting, and décollement in a stretched crust. Tectonics, 2:345-356.

Bukovics, C., Shaw, N. D., Cartier, E. G., and Ziegler, P. A., 1984. Structure and development of the Mid-Norway continental margin. In Spencer, A. M., et al. (Eds.), Petroleum Geology of the North European Margin: London (Graham and Trotman), 407-423.

Buckovics, C., and Ziegler P. A., 1985. Tectonic development of the Mid-Norway continental margin. Mar. Pet. Geol., 2:2-22.

Bøen, F., Eggen, S., and Vollset, J., 1984. Structures and basins of the margin from $62-69^{\circ} \mathrm{N}$ and their development. In Spencer, A. M., et al. (Eds.), Petroleum Geology of the North European Margin: London (Graham and Trotman), 253-270.

Caston, V.N.D., 1976. Tertiary sediments of the Vøring Plateau, Norwegian Sea, recovered by Leg 38 of the Deep Sea Drilling Project. In
Talwani, M., Udintsev, G., et al., 1976, Init. Repts. DSDP, 38: Washington DC (U.S. Govt. Printing Office), 761-782.

Dalland, A., and Worsley, D., 1988. A lithostratigraphic scheme for the Mesozoic and Cenozoic succession offshore Norway north of $62^{\circ} \mathrm{N}$. Norwegian Petrol. Directorate, Bull. 4.

Eldholm, O., and Windisch, C. C., 1974. Sediment distribution in the Norwegian-Greenland Sea. Bull. Geol. Soc. Am., 85:1661-1676.

Eldholm, O., and Mutter, J. C., 1986. Basin structure of the Norwegian margin from analysis of digitally recorded sonobuoys. J. Geophys. Res., 91:3763-3783.

Eldholm, O. Sundvor, E., Myhre, A. M., and Faleide, J. I., 1984. Cenozoic evolution of the continental margin off Norway and western Svalbard. In Spencer, A. M., et al. (Eds.), Petroleum Geology of the North European Margin: London (Graham and Trotman), 3-28.

Eldholm, O., Skogseid, J., Sundvor, E. and Myhre, A. M., 1989. The Norwegian-Greenland Sea. In: Grantz, A., Johnson, G. L., and Sweeney, J. (Eds.), The Arctic Ocean Region, Vol. L, The Geology of North America: Boulder (Geol. Soc. Am.).

Eldholm, O., Thiede, J., Taylor, E., et al., 1987. Proc. ODP, Init. Repts., 104: College Station, TX (Ocean Drilling Program).

Gabrielsen, R. H., 1986. Structural elements in graben systems and their influence on hydrocarbon trap types. In Spencer, A. M., et al. (Eds.), Habitat of hydrocarbons on the Norwegian Continental Shelf: London (Graham and Trotman), 55-60.

Gabrielsen, R. H., in press. Reactivation of faults on the Norwegian Continental Shelf and its implication for earthquake occurrence. In Basham, P., and Gregersen, S. (Eds.), Causes and effects of earthquakes at passive margins and in areas with postglacial rebound on both sides of the North Atlantic: Proc. Nato Adv. Res. Worksh. (Elsevier).

Gabrielsen, R. H., and Robinson C., 1984. Tectonic inhomogeneities of the Kristiansund-Bodø Fault complex, offshore mid-Norway. In Spencer, A. M., et al. (Eds.), Petroleum Geology of the North European Margin: London (Graham and Trotman), 397-406.

Gabrielsen, R. H., Faerseth, R., Hamar, G., and Rønnevik, H. C., 1984. Nomenclature of the main structural features on the Norwegian Continental Shelf north of the 62nd parallel. In Spencer, A. M., et al. (Eds.), Petroleum Geology of the North European Margin: London (Graham and Trotman), 417-460.

Gatliff, R. W., Hitchen, K., Ritchie, J. D., and Smythe, R. K., 1984. Internal structure of the Erlend Tertiary volcanic complex, north of Shetland, revealed by seismic reflection. J. Geol. Soc. London, 141: 555-562.

Gibb, F.G.F., and Kanaris-Sotiriou, R., 1988. The geochemistry and origin of the Faeroes-Shetlands sill complex. In Morton, A. C., and Parson, L. M. (Eds.), Early Tertiary volcanism and the opening of the NE Atlantic. Geol. Soc. London Spec. Publ., 39:241-252.

Gibb, F.G.F., Kanaris-Sotiriou, R., and Neves, R., 1986. A new Tertiary sill complex of mid-ocean ridge basalt type NNE of the Shetland Isles: a preliminary report. Trans. R. Soc. Edinburgh: Earth Sci., 77:223-230.

Gowers, M. B., and Lunde, G., 1984. The geological history of Traenabanken. In Spencer, A. M., et al. (Eds.), Petroleum Geology of the North European Margin: London (Graham and Trotman), 237-252.

Gravdal, N., 1985, The Møre Basin [Cand. sci. thesis], University of Oslo, Norway.

Hagevang, T., and Rønnevik, H. C., 1986. Basin development and hydrocarbon occurence offshore Mid-Norway. AAPG Mem., 40:599613.

Hagevang, T., Eldholm, O., and Aalstad, I., 1983. Pre-23 magnetic anomalies between Jan Mayen and Greenland-Senja fracture zones in the Norwegian Sea. Mar. Geophys. Res., 5:345-363.

Hamar, G. P., and Hjelle, K., 1984, Tectonic framework of the Møre Basin and northern North Sea. In Spencer, A. M., et al. (Eds.), Petroleum Geology of the North European Margin: London (Graham and Trotman), 349-358.

Harding, T. P., and Lowell, J. D., 1979. Structural styles, their plate-tectonic habitats, and hydrocarbon traps in petroleum provinces. $A A P G$ Bull., 63:1016-1058.

Hastings, D. S., 1986. Cretaceous stratigraphy and reservoir potential, mid Norway continental shelf. In Spencer, A. M., et al. (Eds.), Habitat of hydrocarbons on the Norwegian continental shelf. London (Graham \& Trotman), 287-298. 
Hinz, K., Dostman, H. J., and Hanisch, J., 1982. Structural framework of the Norwegian Sea. In Offshore Northern Seas: Oslo (Norwegian Petrol. Soc.).

Hinz, K., Dostman, H. J., and Hanisch, J., 1984. Structural elements of the Norwegian Sea continental margin. Geol. Jahrb., A75:193211.

Hinz, K., Mutter, J. C., Zehnder, C. M., and NGT Study Group, 1987. Symmetric conjugation of continent-ocean boundary structures along the Norwegian and East Greenland margins. Mar. Pet. Geol., 4:166187.

Hitchen, K., and Ritchie, J. D., 1987. Geological review of the West Shetland area. In Brooks, J., and Glennie, K. (Eds.), Petroleum Geology of North West Europe: London (Graham \& Trotman), 737749.

Hollander, N. B., 1984. Geohistory and hydrocarbon evaluation of the Haltenbanken area. In Spencer, A. M., et al. (Eds.), Petroleum Ge ology of the North European Margin: London (Graham and Trotman), 383-388.

Jacqué, M., and Thouvenin, J., 1975. Lower Tertiary tuffs and volcanic activity in the North Sea. In Woodland, A. M. (Ed.), Petroleum and the continental shelf of North-west Europe, Vol. 1: London (Applied Sci. Pubs.), 455-465.

Jansa, L. F., and PePepier, G., 1988. Middle Jurassic to early Cretaceous igneous rocks along Eastern North American continental margin. AAPG Bull., 72:347-366.

Jenyon, M. K., 1987. Characteristics of some igneous extrusive and hypabyssal features in seismic data. Geology, 15:237-240.

Jørgensen, F., and Navrestad, T., 1981. The geology of the Norwegian shelf between $62^{\circ} \mathrm{N}$ and the Lofoten Islands. In Illing, L. V., and Hobson, G. D. (Eds.), Petroleum geology of the continental shelf of NW Europe: London (Institute of Petroleum), 407-413.

Kaminski, M. A., 1987. Cenozoic deep-water agglutinated foraminifera in the North Atlantic [Ph. D. thesis], Woods Hole Oceanogr. Inst., Mass.

Knox, R.W.O'B., 1984. Nannoplankton zonation and the Palaeocene/ Eocene boundary beds of NW Europe: An indirect correlation by means of volcanic ash layers, J. Geol. Soc. London, 141:993-999.

Knox, R.W.O'B., and Morton, A. C., 1988. The record of early Tertiary North Atlantic volcanism in sediments of the North Sea Basin. In Morton, A. C., and Parson, L. M. (Eds.), Early Tertiary volcanism and the opening of the NE Atlantic, Geol. Soc. London Spec. Publ., 39:407-419.

Larsen, R. M., and Skarpnes, O., 1984. Regional interpretation and hydrocarbon potential of the Traenabanken area. In Spencer, A. M., et al. (Eds.), Petroleum Geology of the North European Margin: London (Graham and Trotman), 217-236.

Larsen, V. B., 1987. A synthesis of tectonically-related stratigraphy in the North Atlantic-Arctic region from Aalenian to Cenomanian time. Norsk Geol. Tidskr., 67:281-293.

Le Pichon, X., and Sibuet, J-C., 1981. Plate boundaries and extensional tectonics. J. Geophys. Res., 81:239-256.

Malm, O. A., Christensen, O. B., Østby, K. L., Furnes, H., Løvlie, R., and Rueslâtten, H., 1984. The lower Tertiary Balder Formation: An organogenic and tuffaceous deposit in the North Sea region. In Spencer, A. M., et al. (Eds.), Petroleum Geology of the North European Margin: London (Graham and Trotman), 149-170.

McKenzie, D., 1978. Some remarks on the development of sedimentary basins. Earth Planet. Sci. Lett., 74:25-32.

Mudge, D. C., and Rashid, B., 1987. The geology of the Faeroe Basin area. In Brooks, J., and Glennie K., (Eds.), Petroleum Geology of North West Europe: London (Graham \& Trotman), 751-763.

Mutter, J. C., 1984. Cenozoic and late Mesozoic stratigraphy and subsidence history of the Norwegian margin. Bull. Geol. Soc. Am., 95: $1135-1149$.

Mutter, J. C., and Zehnder, C. M., 1988. Deep crustal structure and magmatic processes: The inception of seafloor spreading in the Norwegian-Greenland Sea. In Morton, A. C., and Parson, L. M. (Eds.). Early Tertiary volcanism and the opening of the NE Atlantic, Geol. Soc. London Spec. Publ., 39:35-48.

Mutter, J. C., Talwani, M., and Stoffa, P. L., 1984. Origin of seawarddipping reflectors in oceanic crust off the Norwegian margin by "subaerial sea-floor spreading." J. Geophys. Res., 89:483-502.
Mutter, J. C., Buck, W. R., and Zehnder C. M., 1988. Convective partial melting. 1. A model for the formation of thick basaltic sequences during the initiation of spreading. J. Geophys. Res., 93: 1031-1048.

Perry, R. B., Flemming, H. S., Cherkis, N. Z., Feden, R. H., and Vogt, P. R., 1980. Bathymetry of the Norwegian-Greenland and western Barents seas. Map, U.S. Naval Res. Lab., Washington D.C.

Price, I., and Rattey, P. R., 1984. Cretaceous tectonics of mid-Norway. J. Geol. Soc. London, 141:985-992.

Rønnevik, H. C., and Navrestad, T., 1977. Geology of the Norwegian shelf between $62^{\circ} \mathrm{N}$ and $69^{\circ} \mathrm{N}$. GeoJournal, 1:33-46.

Rønnevik, H. C., Jørgensen, F., and Motland, K., 1979. The geology of the northern part of the Vøring Plateau. Rept. NSS/12, Norwegian Petrol. Soc.

Rønnevik, H. C., Eggen, S., and Vollset, J., 1983. Exploration of the Norwegian Shelf. In Brooks, J. (Ed.), Petroleum Geochemistry and Exploration of Europe: Oxford (Blackwell), 71-94.

Schrader, H-J., Bjørklund, K. R., Manum, S. B., Martini, E., and van Hinte, J., 1976. Cenozoic biostratigraphy, physical stratigraphy and paleoceanography in the Norwegian-Greenland Sea, DSDP Leg 38. In Talwani, M., Udintsev, G., et al., Init. Repts. DSDP, 38: Washington (U.S. Govt. Printing Office), 1197-1211.

Schuepbach, M. A., and Vail, P. R., 1980. Evolution of outer highs on divergent continental margins. In Burchfield, B. C., et al. (Eds.), Continental Tectonics: Studies in Geophysics: National Res. Council (Washington), 50-64.

Shelton, J.W., 1984, Listric normal faults: An illustrated summary. AAPG Bull., 68:801-815.

Skogseid, J., 1983. Geophysical studies between Vøring Plateau margin and the Jan Mayen Ridge and a plate tectonic model for the evolution of the Norway Basin [Cand. Sci. thesis]. Univ. of Oslo, Norway.

Skogseid, J., and Eldholm, O., 1987. Early Cenozoic crust at the Norwegian continental margin and the conjugate Jan Mayen Ridge. $J$. Geophys. Res., 92:11471-11491.

Skogseid, J., and Eldholm, O., 1988. Early Cenozoic evolution of the Norwegian volcanic passive margin and the formation of marginal highs. In Morton, A. C., and Parson, L. M. (Eds.), Early Tertiary volcanism and the opening of the NE Atlantic, Geol. Soc. London Spec. Publ., 39:49-56.

Smith, R. B., and Bruhn, R. L., 1984. Intraplate extensional tectonics of the eastern basin-range: Inferences on structural style from seismic reflector data, regional tectonics, and thermal-mechanical models of brittle-ductile deformation. J. Geophys. Res., 89:5733-5762.

Smythe, D. K., 1983. Faeroe-Shetland Escarpment and continental margin north of the Faeroes. In Bott, M.H.P., Saxov, S., Talwani, M., and Thiede, J. (Eds.), Structure and Development of the GreenlandScotland Ridge-New Methods and Concepts: New York (Plenum Press), 109-119.

Smythe, D. K., Chalmers, J. A., Skuce, A. G., Dobinson, A., and Mould, A. S., 1983, Early opening history of the North Atlantic-I. Structure and origin of the Faeroe-Shetland Escarpment. Geophys. J. R. Astron. Soc., 72:373-398.

Talwani, M., and Eldholm, O., 1972. The continental margin off Norway: A geophysical study. Geol. Soc. Am. Bull., 83:3575-3608.

Talwani, M., and Eldholm, O., 1973. The boundary between continental and oceanic crust at the margin of rifted continents. Nature, 241: 325-330.

Talwani, M., and Eldholm, O., 1977. Evolution. of the NorwegianGreenland Sea. Geol. Soc. Am. Bull., 88:969-999.

Talwani, M., Udintsev, G., 1976. Tectonic synthesis. In Talwani, M., Udintsev, G., et al., 1976. Init. Repts. DSDP, 38: Washington (U.S. Govt. Printing Office), 1213-1242.

Talwani, M., Mutter, J. C., and Hinz, K., 1983. Ocean continent boundary under the Norwegian continental margin. In Bott, M.H.P., Saxov, S., Talwani, M., and Thiede, J. (Eds.), Structure and Development of the Greenland-Scotland Ridge-New Methods and Concepts: New York (Plenum Press), 121-131.

Talwani, M., Udintsev, G., et al., 1976. Init. Repts. DSDP, 38: Washington (U.S. Govt. Printing Office). 
Theilen, F., Uenzelmann, G., and Gimpel, P., 1987. Sediment distribution at the outer Vøring Plateau from reflection seismic investigations. In Sonderforschungsbereich 313. Sedimentation im Europäischen Nordmeer, University of Kiel, 566-593.

Vail, P. R., Mitchum, R. M., and Thompson, S., 1977. Seismic stratigraphy and global changes of sea level. Part 4: Global cycles of relative changes of sea level. Am. Assoc. Petrol. Geol. Mem., 26:83-87.
White, R. S., Spence, G. D., Fowler, S. R., McKenzie, D. P., Westbrook, G. K., and Bowen, A. N., 1987. Magmatism at rifted continental margins. Nature, 330:439-444.

Date of initial receipt: 3 June 1988

Date of acceptance: 7 Sept. 1988

Ms 104B-151 